\title{
Pilot Demonstration of Reclaiming Municipal Wastewater for Irrigation Using Electrodialysis Reversal: Effect of Operational Parameters on Water Quality
}

\author{
Xuesong $\mathrm{Xu}{ }^{1} \mathbb{1}, \mathrm{Qun} \mathrm{He}^{2}$, Guanyu Ma ${ }^{1}$, Huiyao Wang ${ }^{1}$, Nagamany Nirmalakhandan ${ }^{1}$ and Pei $\mathrm{Xu}{ }^{1, *(\mathbb{D})}$ \\ 1 Department of Civil Engineering, New Mexico State University, Las Cruces, NM 88003, USA; \\ xuesong@nmsu.edu (X.X.); gyma@nmsu.edu (G.M.); huiyao@nmsu.edu (H.W.); nkhandan@nmsu.edu (N.N.) \\ 2 Carollo Engineers, Phoenix, AZ 85034, USA; che@carollo.com \\ * Correspondence: pxu@nmsu.edu; Tel.: +1-575-646-5870
}

check for

updates

Citation: Xu, X.; He, Q.; Ma, G.;

Wang, H.; Nirmalakhandan, N.; Xu, P.

Pilot Demonstration of Reclaiming

Municipal Wastewater for Irrigation

Using Electrodialysis Reversal: Effect of Operational Parameters on Water

Quality. Membranes 2021, 11, 333.

https://doi.org/10.3390/

membranes 11050333

Academic Editor: Xin Liu

Received: 9 April 2021

Accepted: 28 April 2021

Published: 30 April 2021

Publisher's Note: MDPI stays neutral with regard to jurisdictional claims in published maps and institutional affiliations.

\begin{abstract}
The modification of ion composition is important to meet product water quality requirements, such as adjusting the sodium adsorption ratio of reclaimed water for irrigation. Benchand pilot-scale experiments were conducted using an electrodialysis reversal (EDR) system with Ionics normal grade ion-exchange membranes (CR67 and AR204) to treat the reclaimed water in the Scottsdale Water Campus, Arizona. The goal is to investigate the impact of operating conditions on improving reclaimed water quality for irrigation and stream flow augmentation. The desalting efficiency, expressed as electrical conductivity (EC) reduction, was highly comparable at the same current density between the bench- and pilot-scale EDR systems, proportional to the ratio of residence time in the electrodialysis stack. The salt flux was primarily affected by the current density independent of flow rate, which is associated with linear velocity, boundary layer condition, and residence time. Monovalent-selectivity in terms of equivalent removal of divalent ions $\left(\mathrm{Ca}^{2+}, \mathrm{Mg}^{2+}\right.$, and $\mathrm{SO}_{4}{ }^{2-}$ ) over monovalent ions $\left(\mathrm{Na}^{+}, \mathrm{Cl}^{-}\right)$was dominantly affected by both current density and water recovery. The techno-economic modeling indicated that EDR treatment of reclaimed water is more cost-effective than the existing ultrafiltration/reverse osmosis (UF/RO) process in terms of unit operation and maintenance cost and total life cycle cost. The EDR system could achieve $92-93 \%$ overall water recovery compared to $88 \%$ water recovery of the UF/RO system. In summary, electrodialysis is demonstrated as a technically feasible and cost viable alternative to treat reclaimed water for irrigation and streamflow augmentation.
\end{abstract}

Keywords: electrodialysis; reclaimed water; desalination; ion-exchange membranes; ion permselectivity; irrigation

\section{Introduction}

The development of alternative water supplies such as municipal wastewater has been a viable solution to address the challenges of water scarcity and impaired water quality that have influenced human activities and the environment [1-3]. Reclaimed water has been used for irrigation of turf and crops [4,5], groundwater recharge [6,7], potable reuse [8], cooling water for power plants [9], and other municipal and industrial applications [10]. The total dissolved solids (TDS) in such reclaimed water sources (usually above $1000 \mathrm{mg} / \mathrm{L}$ ) and elevated concentrations of specific ions (e.g., sodium, calcium, chloride, nitrate, and sulfate) can adversely impact potential beneficial use [11,12]. For instance, the use of reclaimed water containing high sodium concentration for agricultural and golf course irrigation would degrade soil condition $[13,14]$, while the discharge of high chloride water may jeopardize surface water discharge permit compliance due to failure of the Whole Effluent Toxicity (WET) test [15].

Reverse osmosis (RO) is currently the primary membrane separation process for water desalination and reuse [16,17]. However, the application of RO is hindered by 
high energy demand, membrane scaling and fouling, and limited options for concentrate disposal [18]. Electrodialysis or electrodialysis reversal (EDR) that utilizes an electrical potential difference between the electrodes and ion-exchange membranes (IEMs) to remove salt ions provides an alternative to desalinate brackish water and wastewater $[19,20]$. The tendency of membrane scaling and fouling in electrodialysis can be significantly reduced because of paralleling water flow paths along the IEM surface (not passing through membranes) and relatively loose scaling/fouling layer due to low hydraulic pressure applied [21]. EDR enables the same electrochemical separation process as electrodialysis, except periodic reversal of the electrical polarity of the electrodes to inhibit deposition of potential scaling/fouling on the IEM surface [22,23]. In addition, electrodialysis barely rejects neutral species such as silica and organic matter, thereby further reducing the fouling and scaling propensity. Unlike $\mathrm{RO}$ that produces high purity permeate and requires posttreatment and stabilization to generate final product water, electrodialysis can flexibly tailor the desalination level and control ion composition in product water by adjusting operating parameters such as applied voltage, flow rate, and staging of the electrodialysis stacks. The electrodialysis process can directly produce product water with the desired water quality, thus avoiding the complexity of stabilizing the product water after desalination [24-26]. Therefore, electrodialysis could be a more cost-effective and energy-saving process than $\mathrm{RO}$ for desalination of impaired water sources for non-potable water reuse applications.

Electrodialysis has been a commercial technology for decades, primarily for groundwater desalination. There is an increasing interest in electrodialysis for various applications including irrigation because of its selective separation capacity. More investigation of wastewater treatment using electrodialysis is needed to explore the transport behaviors of ions in multi-component solutions due to the complex interactions of ions in the solutions and competing transport of different ions through IEMs simultaneously [27]. Currently, most electrodialysis studies in treating reclaimed water were conducted in laboratory-scale systems with synthetic or real solutions [28-32]. It is critical to treat wastewater at scaleup electrodialysis systems for evaluating the feasibility and economic viability through long-term near full-scale operations, and bridging bench- and pilot-scale experiments to predicting commercial implementation [33,34].

In addition, the impacts of operational parameters need to be thoroughly analyzed at large-scale electrodialysis system for system design and operation. The applied voltage and current density (Equation (3) in Supplemental Information) are of importance for the overall performance of electrodialysis system [35]. The flow rate, associated with linear velocity, is also a key operating parameter to determine overall desalination and energy efficiencies because it affects the degree of mixing and controls the residence time of the desalting water inside the electrodialysis stacks [36,37]. Therefore, the net influence of flow rate on the salt transfer rate merits further investigation for reclaiming wastewater. As scaling can pose a challenge for treating wastewater using electrodialysis at high water recovery $[38,39]$, the impact of hydraulic water recovery is also worth being evaluated under various operating conditions.

This study investigated the application of electrodialysis to treat reclaimed water for golf course irrigation and instream flow augmentation. A bench-scale electrodialysis unit and a 2 electrical stage pilot-scale EDR system manufactured by the Suez Water Technologies \& Solutions were operated continuously at an advanced wastewater treatment facility in Scottsdale, Arizona, USA, to investigate the technical feasibility and economic viability of the electrodialysis process for treating reclaimed water under different operating conditions. The reclaimed water needs to meet a sodium goal of $110 \mathrm{mg} / \mathrm{L}$ for golf course irrigation and a chloride goal of $150 \mathrm{mg} / \mathrm{L}$ to reduce the risks of WET failure for instream flow augmentation. The City of Scottsdale utilizes ultrafiltration (UF) as pretreatment and subsequent $\mathrm{RO}$ to desalinate a partial stream of the reclaimed water and blend it with the remaining stream. This approach requires subsequent blending and stabilization for final product water and generates a $\mathrm{RO}$ concentrate that requires proper disposal. 
The present study aims to evaluate the use of EDR as an alternative to UF/RO for treating the reclaimed water for non-potable water reuse, e.g., irrigation and in-stream augmentation. The main objectives of the study include the following: (1) assess the sodium and chloride removal behavior in treating the reclaimed water to meet the target water quality requirements for golf course irrigation and surface water discharge; (2) evaluate the impacts of pilot-scale EDR configuration (e.g., number of staging and cell pairs) and operating conditions (e.g., applied voltage, flow rate, and water recovery) on desalination performance and ion composition of the product water; (3) compare the desalting performance between bench- and pilot-scale electrodialysis for system scaleup and optimization; and (4) conduct a techno-economic analysis of the EDR process in comparison to the existing UF/RO system.

\section{Materials and Methods}

\subsection{Water Quality and Analysis}

The bench- and pilot-scale experiments were conducted at the Scottsdale Water Campus, Arizona, treating the denitrified tertiary effluent from the wastewater treatment plant (WWTP). During the testing period, the TDS concentration of the reclaimed water was $1131 \pm 34 \mathrm{mg} / \mathrm{L}$ with an electrical conductivity of $1812 \pm 61 \mu \mathrm{S} / \mathrm{cm}$. The major ions in the reclaimed water included $\mathrm{Na}^{+}(246 \pm 30 \mathrm{mg} / \mathrm{L}), \mathrm{Ca}^{2+}(85 \pm 8 \mathrm{mg} / \mathrm{L}), \mathrm{Mg}^{2+}$ $(29 \pm 1.4 \mathrm{mg} / \mathrm{L}), \mathrm{K}^{+}(23 \pm 1.2 \mathrm{mg} / \mathrm{L}), \mathrm{Cl}^{-}(350 \pm 18 \mathrm{mg} / \mathrm{L}), \mathrm{SO}_{4}{ }^{2-}(253 \pm 32 \mathrm{mg} / \mathrm{L})$, and $\mathrm{SiO}_{2}(12.5 \pm 1.1 \mathrm{mg} / \mathrm{L})$. The relatively high concentrations of sodium and chloride make the reclaimed water unsuitable for beneficial reuse, specifically for irrigation in this case. The concentrations of other minor ions such as arsenic, phosphate, iron, manganese, nitrite, nitrate, bromide, and fluoride were negligible to impact the desalination performance. The $\mathrm{pH}$ of the reclaimed water was $7.4 \pm 0.1$, and the alkalinity was $155 \pm 20 \mathrm{mg} / \mathrm{L}$ as $\mathrm{CaCO}_{3}$. The total organic carbon (TOC) concentration in the reclaimed water was $7.7 \pm 0.15 \mathrm{mg} / \mathrm{L}$.

The electrical conductivity and $\mathrm{pH}$ of the water samples were measured using a conductivity and pH meter (Model 431-61, Cole-Parmer, Vernon Hills, IL, USA). The TOC was determined by a carbon analyzer (Shimadzu TOC-L, Kyoto, Japan), and major ions were measured using an ion chromatograph (IC, ICS-2100, Dionex, Sunnyvale, CA, USA). The concentrations of trace metallic elements were quantified using inductively coupled plasma mass spectrometry (ICP-MS, Elan DRC-e, PerkinElmer, Waltham, MA, USA). Alkalinity was measured using a digital titrator (Hach, Loveland, CO, USA) and 1.6 $\mathrm{N}$ sulfuric acid standard solution. The TDS concentration was measured following the evaporation method at $180^{\circ} \mathrm{C}$ after filtering the water samples using a $0.45 \mu \mathrm{m}$ cellulose acetate membrane filter (Toyo Roshi Kaisha, Ltd., Japan).

\subsection{Bench- and Pilot-Scale Electrodialysis Systems}

The mobile, trailer-mounted EDR system (AQ3-1-4, Suez Wvs. ater Technologies \& Solutions, Guelph, Ontario, Canada) is a pilot version of a commercial full-scale water treatment plant (Figure 1). The pilot-scale EDR system can generate 3 to 13 gallons per minute (gpm, or 11.3 to $49 \mathrm{~L}$ per minute, L/min) product water. The Ionics normal grade IEMs (AR204-SZRA-412 and CR67-HMR-412, Suez Water Technologies \& Solutions, Guelph, Ontario, Canada) were used for the bench- and pilot-scale electrodialysis testing. The thickness of the membranes is $0.6 \mathrm{~mm}$ for cation-exchange membranes CR67 and $0.5 \mathrm{~mm}$ for anion-exchange membranes AR204. Both IEMs have the same water content of $46 \%$. The ion exchange capacity (IEC) of AR204 was higher than the CR67 (2.4 vs. $2.1 \mathrm{meq} / \mathrm{g}$ dry membrane), while the area electrical resistance of the AR204 measured in $0.01 \mathrm{~N} \mathrm{NaCl}$ solution was lower than the CR67 (8 vs. $12 \mathrm{ohm}-\mathrm{cm}^{2}$ ). The patented mesh spacers (Mark IV-2) have a thickness of $0.076 \mathrm{~cm}$ and provide flow channel and mixing for each stream in the EDR unit [40]. Platinum plated titanium metal plates were used as electrodes to apply electrical potential to the stack. One hundred cell pairs of CR67 and AR204, with effective area approximately $3200 \mathrm{~cm}^{2}\left(3.44 \mathrm{ft}^{2}\right)$ for each membrane, were 
installed in the EDR stack with 2 electrical stage and 2 hydraulic stage. Each stage had 50 pairs of membranes. An independent voltage source was applied to each electrical stage.

Reclaimed water

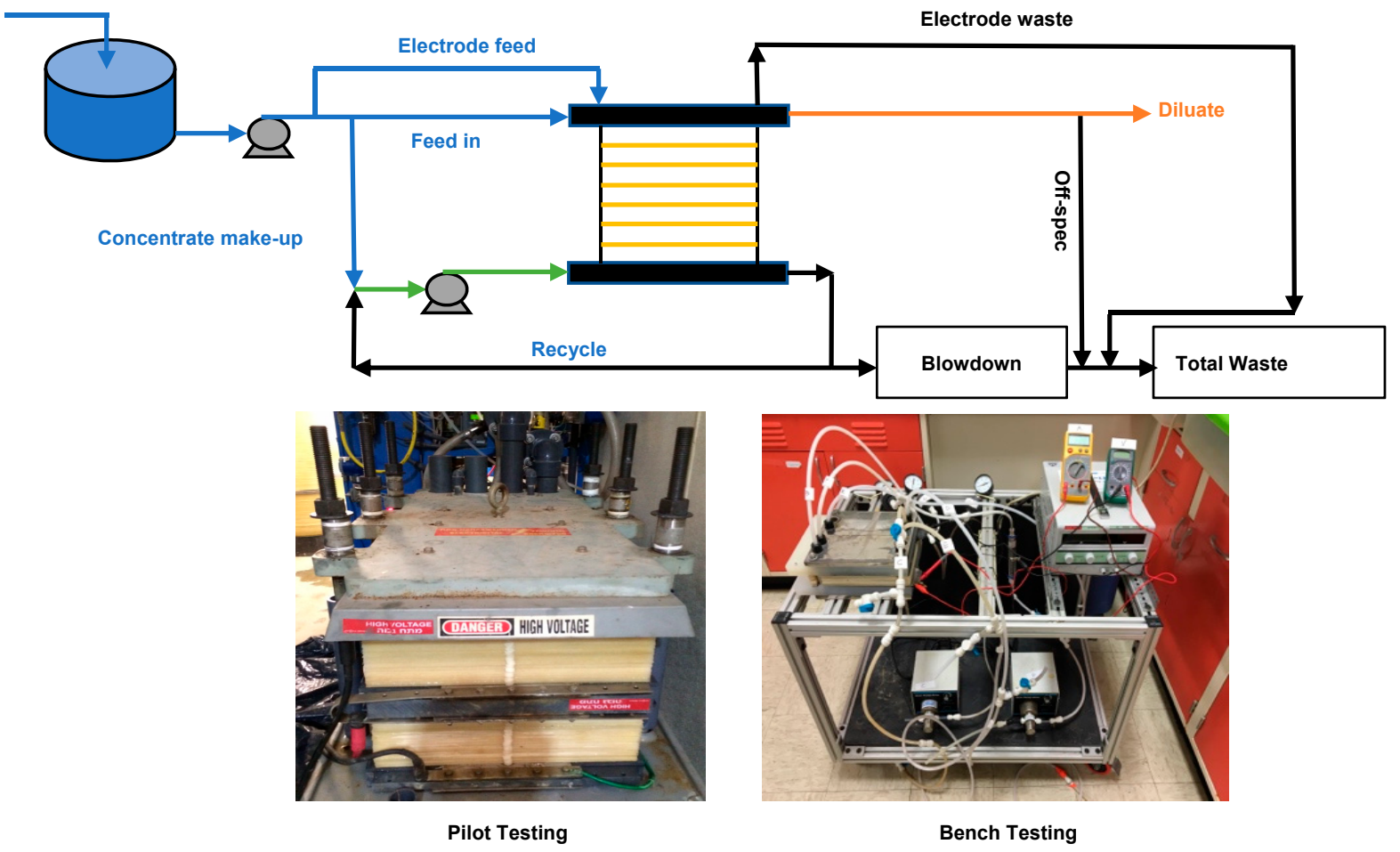

Figure 1. Schematic flow diagram of the electrodialysis systems.

An in-line $10 \mu \mathrm{m}$ cartridge filter was installed as a pretreatment step before the reclaimed water entering the electrodialysis stack. Feedwater was split into three streams: (I) a stream of feedwater (feed in) was progressively demineralized as desalted water (product water or diluate); (II) a stream of feedwater was used as concentrate make-up to be mixed with concentrate recycled as the inlet concentrate; and (III) a small stream of feedwater $(<4 \%)$ was diverted into the electrode rinsing stream. A blower was installed to remove the chlorine gas generated in the electrode rinse waste stream. The electrode rinse solution can be replaced by another source of aqueous solution (e.g., $\mathrm{Na}_{2} \mathrm{SO}_{4}$ solution) to avoid the generation of chlorine gas.

The pilot-scale EDR stack reversed electrical polarity automatically every $15 \mathrm{~min}$. The current in the positive polarity mode was slightly smaller than that in the negative polarity mode, which had relatively lower value of electrical conductivity in product water. All the reported data herein were from the water samples obtained during the positive polarity mode, which had similar water quality as in the negative polarity. Within the first minute after polarity change, foulants and scales were flushed off from the IEMs surfaces, and the product water (namely off-spec water) could not meet the required water quality. A real-time conductivity sensor was installed in the diluate stream outlet to monitor the water quality and control a diversion valve to steer the off-spec water into the waste stream when its TDS exceeded the product water quality control level. Both off-spec and electrode rinsing water were diverted into the waste stream, which can be recycled to the feedwater tank for further enhancing water recovery in the EDR system.

Different water recoveries (Equation (2) in Supplemental Information) were achieved by adjusting the flow rates of the concentrate blowdown, feed in, and concentrate make-up. For example, to achieve an overall $50 \%$ water recovery, the total inlet feedwater was $14 \mathrm{gpm}$ $(53 \mathrm{~L} / \mathrm{min})$ to produce $7.5 \mathrm{gpm}(28.4 \mathrm{~L} / \mathrm{min})$ product water. Considering the water loss 
as off-spec water ( $~ 7 \%$ of product water), electrode rinsing waste $0.53 \mathrm{gpm}(2 \mathrm{~L} / \mathrm{min})$, concentrate make-up stream $5.8 \mathrm{gpm}(22.0 \mathrm{~L} / \mathrm{min})$, the overall water recovery was $50 \%$. Operating parameters, including applied voltage, current density, $\mathrm{pH}$, electrical conductivity, pressure, and flow rate of each water stream, were recorded by the supervisory control and data acquisition system (SCADA, Allen-Bradley, Milwaukee, WI, USA). The polyphosphate antiscalant (Hypersperse, MDC714, Suez Water Technologies \& Solutions) with injection dosage $(19 \mathrm{mg} / \mathrm{L})$ calculated by the predictive WATSYS ${ }^{\mathrm{TM}}$ program was pumped continuously into the concentrate stream to inhibit scale formation/precipitation on the IEM surface. The WATSYS ${ }^{\mathrm{TM}}$ program was developed by Suez Water Technologies \& Solutions for designing full-scale EDR systems.

A bench-scale electrodialysis system with the same flow design as the pilot unit was operated independently alongside the pilot-scale EDR system to optimize the desalination performance and scale-up from the bench- to pilot-scale systems. The bench-scale laboratory unit included eleven pieces of CR67 and ten pieces of AR204 membranes, each with $220 \mathrm{~cm}^{2}\left(0.24 \mathrm{ft}^{2}\right)$ effective membrane area. The variable-flow micro-pumps (EW-75211-10, Cole-Parmer, Vernon Hills, IL, USA) were chosen to provide desired flow rates and pressure while minimizing pressure fluctuation inside the bench-scale electrodialysis stack. The two electrodialysis systems had the same stack design, configuration of spacers, and IEMs, which made a highly defensible comparison between the bench- and pilot-scale experiments possible. Before each experiment, all new membranes were equilibrated with the reclaimed water for at least $24 \mathrm{~h}$. After the three-month pilot-scale testing, the membranes were removed from the pilot-scale EDR stack for membrane autopsy to identify possible fouling/scaling.

\section{Results and Discussion}

\subsection{LCD Measurement}

Limiting current density (LCD) was studied to evaluate the concentration polarization (CP) in the electrodialysis system. Due to higher ion mobility through membrane matrix than that in solution, concentration polarization, also referred to as concentration gradient, was developed at the interface between membrane and solution. With an increase of the applied voltage, ion concentration on the diluate side would approach zero at the interface, and the current per unit effective membrane area at this point was known as LCD [41]. Water splitting occurs when the current density exceeds the LCD, resulting in reduced desalination efficiency by diverting electric energy to produce $\mathrm{H}^{+}$and $\mathrm{OH}^{-}$from water electrolysis and contributing little to ion transport during desalination [42]. Most electrodialysis and EDR systems are commonly operated at a sub-LCD to achieve high energy efficiency [22], making the LCD an essential parameter in the electrodialysis process.

During the bench- and pilot-scale electrodialysis experiments, the applied voltage was increased discretely every ten to fifteen minutes. LCD values were estimated based on the voltage-current response after a steady-state operational condition was reached. Two current-voltage characteristics were adopted to determine the LCD value (Figure 2). The point that the curve slope changes in the voltage-current $(\mathrm{V}-\mathrm{I})$ curve indicated the LCD location in Figure 2a,c. Sometimes it is impractical to identify the slope-changing point in the V-I curve, especially during desalination of high salinity water where consistent linearity of V-I relationship could be observed over a broad applied voltage range [43]. Cowan and Brown [44] developed the well-accepted method of plotting V/I against the 1 / I curve, where the point with the minimum value of $\mathrm{V} / \mathrm{I}$ was determined as the location of LCD (Figure $2 b, d$ ). 


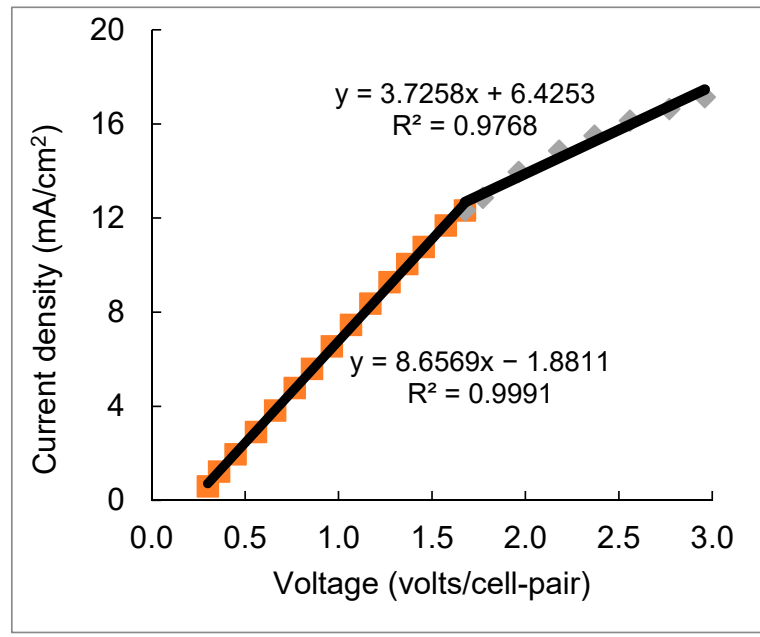

(a)

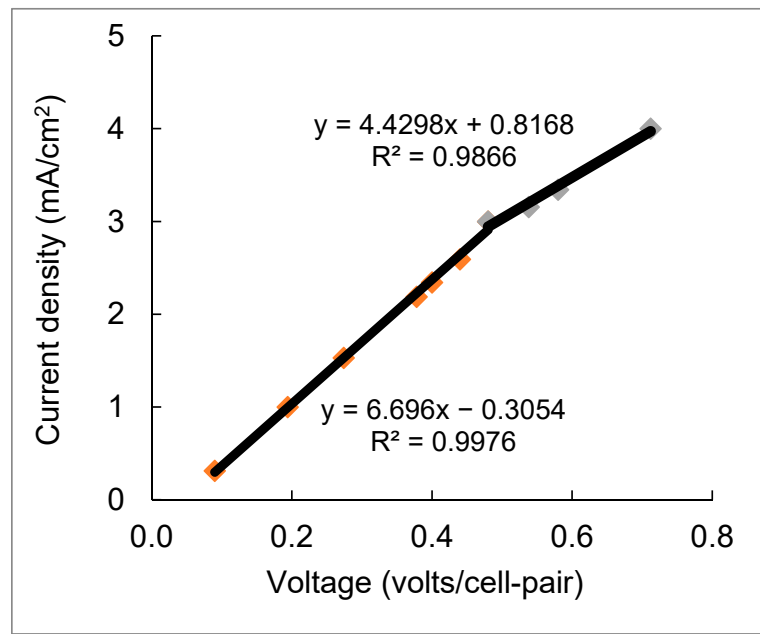

(c)

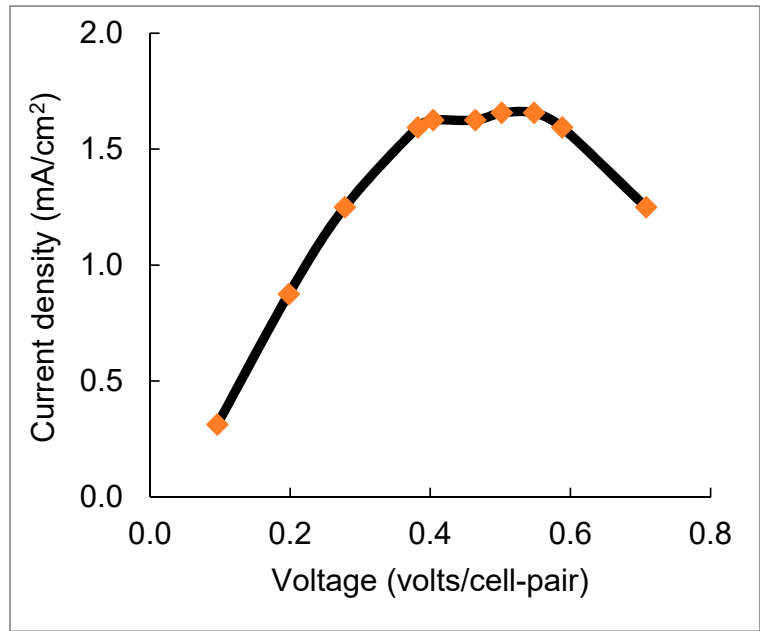

(e)

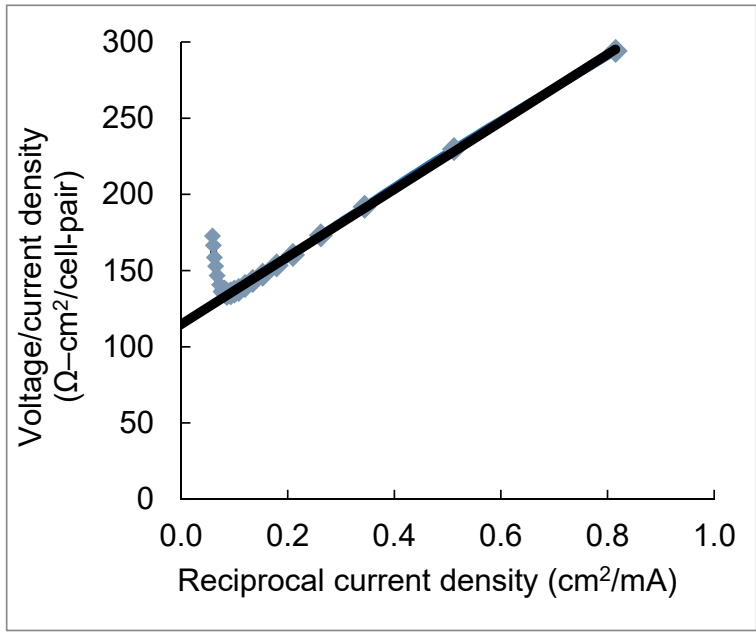

(b)

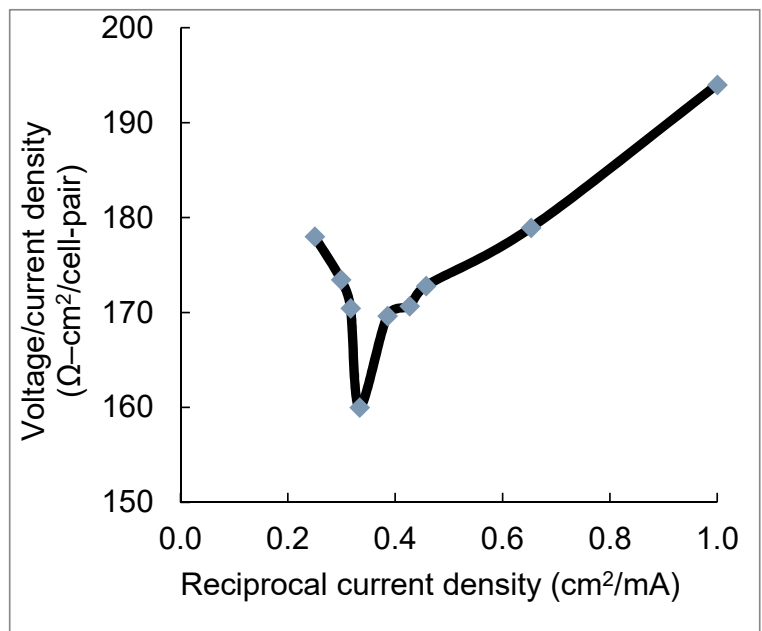

(d)

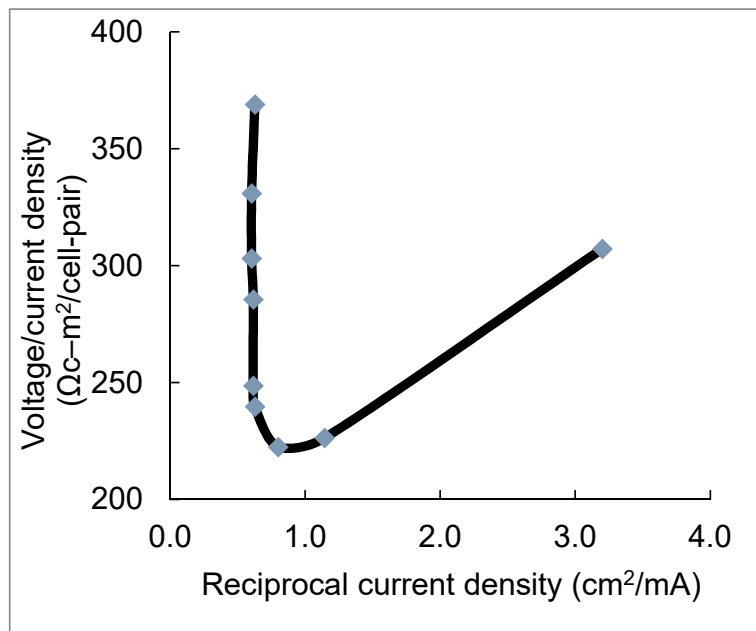

(f)

Figure 2. Determination of limiting current density during electrodialysis of reclaimed water. (a) and (b) V-I and V/I-1/I curves of the bench-scale electrodialysis (ED) system; (c) and (d) V-I and V/I-1/I curves of the $1^{\text {st }}$ electrical stage in the pilot-scale electrodialysis reversal (EDR) system; (e) and (f) V-I and V/I-1/I curves of the $2^{\text {nd }}$ electrical stage in the EDR system. 
The LCD value of the bench-scale unit was identified to be approximately $12 \mathrm{~mA} / \mathrm{cm}^{2}$ (Figure 2a). The slope-turning point of the V/I-1/I curve in bench-scale electrodialysis was located at $135 \Omega-\mathrm{cm}^{2} /$ cell-pair (Figure $2 b$ ), in accordance with the observation in Figure 2a. For the 1st electrical stage of the pilot-scale EDR, the LCD was determined to be $3.0 \mathrm{~mA} / \mathrm{cm}^{2}$ (Figure 2c), while the estimation of the normalized electrical resistance at the LCD was close to $160 \Omega-\mathrm{cm}^{2}$ / cell-pair (Figure 2d). The ohmic regime below the LCD had a highly linear correlation of current density vs. applied voltage in both the bench- and pilot-scale electrodialysis stack $\left(R^{2}>0.99\right)$, revealing nearly constant electrical resistance during desalination within this current density range. Significant electrical resistance jump was encountered above the LCD point due to the depleting ion concentration at the membrane-solution interface, indicating lower energy efficiency compared to that in the ohmic regime. The data for LCD determination were collected during the positive polarity mode. The LCD measured in the negative polarity exhibited a similar trend but slightly lower by $8 \%\left(2.75 \mathrm{~mA} / \mathrm{cm}^{2}\right)$ than the data measured in the positive polarity mode. The 2nd electrical stage of the pilot-scale EDR exhibited different V-I and V/I-1/I behaviors (Figure 2e,f) compared to the $1^{\text {st }}$ electrical stage. A lower minimum point located at current density $1.25 \mathrm{~mA} / \mathrm{cm}^{2}$ with higher normalized electrical resistance $220 \Omega-\mathrm{cm}^{2} /$ cell-pair was detected, due partly to the fact that the inter-stage diluate out, product water of the 1st electrical stage, was the feedwater of the 2 nd electrical stage. LCD was reported to be proportional to feedwater salt concentration [43]. The non-linear V-I curve in the 2nd electrical stage (Figure 2e) was mainly caused by the varying electrical resistance associated with the changing salt concentration in its feedwater [45]. Similar trends were observed in our previous experiments of treating brackish groundwater using the same pilot-scale EDR stack at the Kay Bailey Hutchison Desalination Plant in El Paso, Texas [46].

For the $1^{\text {st }}$ electrical stage, the $\mathrm{pH}$ of the product water decreased from 7.4 (same as the feedwater) to 6.4 with the increase of current density $\left(0.3-4.0 \mathrm{~mA} / \mathrm{cm}^{2}\right)$ in Figure 3, indicating the water dissociation at higher current density [47], while in the concentrate stream, the $\mathrm{pH}$ remained relatively constant at 7.3. The same $\mathrm{pH}$ reduction trend was also observed in the negative polarity mode.

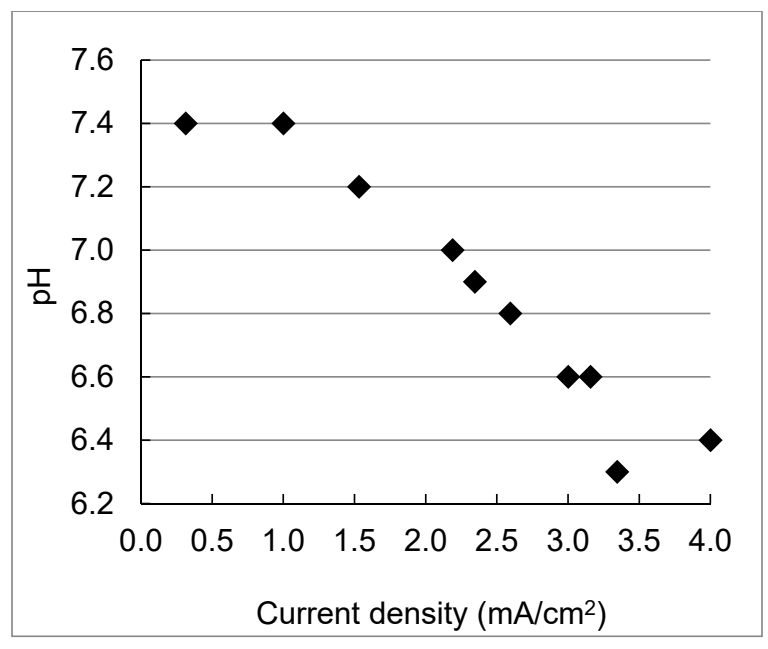

Figure 3. Product water $\mathrm{pH}$ as a function of the current density of the pilot-scale EDR system during electrodialysis of the reclaimed water.

\subsection{Effect of Flow Rate on Desalination Performance}

To study the influence of flow rate on desalination performance, bench-scale experiments were first conducted at a product water flow rate of $1 \mathrm{~L} / \mathrm{min}$ and $1.5 \mathrm{~L} / \mathrm{min}$, corresponding to a linear velocity of 4.1 and $6.1 \mathrm{~cm} / \mathrm{s}$, respectively. The percentage of TDS reduction (Equation (1) in Supplemental Information) decreased with the increase of flow rate from $1 \mathrm{~L} / \mathrm{min}$ and $1.5 \mathrm{~L} / \mathrm{min}$ (hydraulic residence time $13 \mathrm{~s}$ and $9 \mathrm{~s}$, respectively), 
and higher current density was required to achieve the same conductivity reduction at a higher flow rate (Figure 4a). The difference of TDS removal efficiency at the same current density became prominent from $<9 \%$ below the current density of $1.5 \mathrm{~mA} / \mathrm{cm}^{2}$ to $>19 \%$ above the current density of $8.1 \mathrm{~mA} / \mathrm{cm}^{2}$. The positive impact of a higher flow rate on salt removal, associated with higher linear velocity, was attributed to the decreased resistance of the boundary layer by suppressing the diffusion layer between solution and membrane surfaces at the side of diluate streams [48]. On the other hand, decreased residence time at a higher flow rate posed a negative effect on salt removal due to lower residence time for ion separation by passing through IEMs within the electrodialysis stack. The overall negative impact of higher flow rate was observed at the current density below approximately $5.6 \mathrm{~mA} / \mathrm{cm}^{2}$ (Figure $4 \mathrm{~b}$ ), consistent with other observations in bench-scale electrodialysis using normal grade IEMs $[46,49,50]$, which demonstrated the greater influence of residence time over the change of the boundary layer conditions at varying linear velocity.

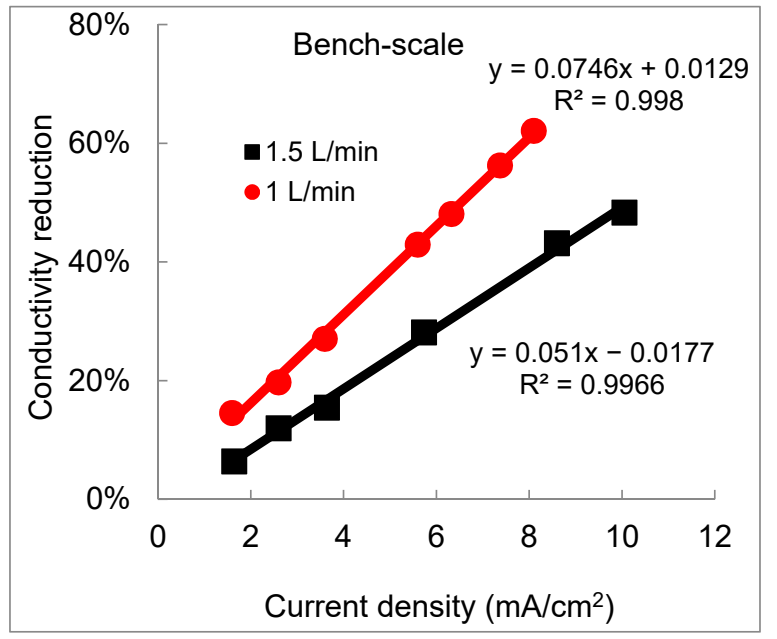

(a)

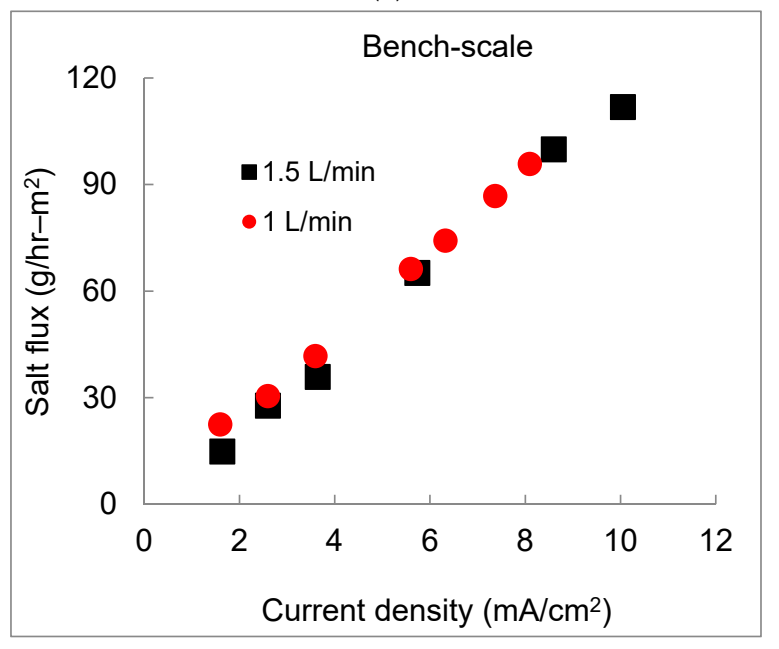

(c)

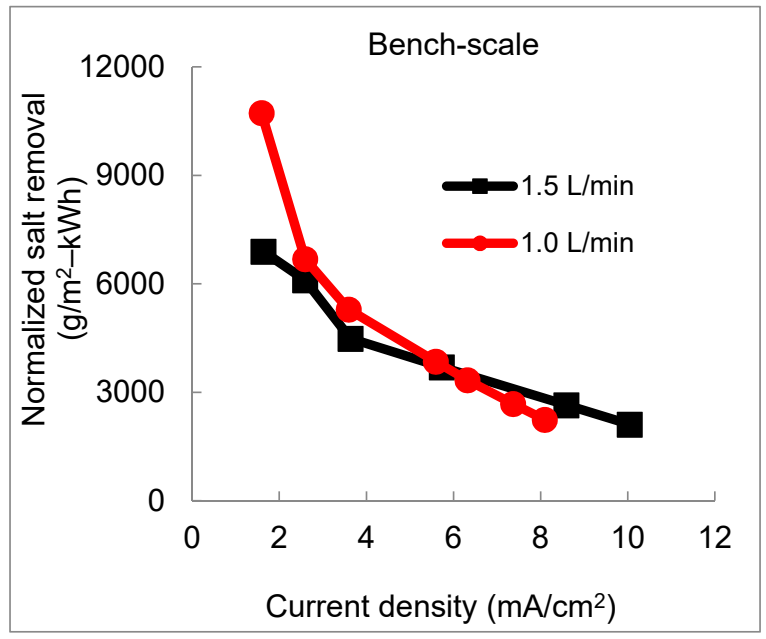

(b)

Figure 4. The effect of flow rate on desalination performance in the bench-scale electrodialysis system. (a) total dissolved solids (TDS reduction efficiency in terms of conductivity reduction; (b) normalized salt removal; and (c) salt flux through IEMs.

With increasing current density, the boundary layer became the limiting factor of ion transport through IEMs due to depletion of ions and sharp concentration gradient within the boundary layer. At a current density greater than $6 \mathrm{~mA} / \mathrm{cm}^{2}$, the significance of positive impact at a higher flow rate prevailed the negative effect of less residence 
time, resulting in slightly enhanced overall normalized salt removal (Equation (5) in Supplemental Information) at a higher flow rate (Figure $4 \mathrm{~b}$ ). The normalized salt removal exhibited a continuously decreasing trend with increase of the current density at both flow rates, which indicated the higher energy consumption at higher desalination requirement.

To predict the specific salt concentration in product water as a function of current density, the absolute ion transport rate (namely, salt flux, Equation (4) in Supplemental Information) from the diluate stream to the concentrate stream was calculated. Salt flux through IEMs under different flow rates is depicted in Figure 4c. The identical linear correlation between salt flux and current density demonstrated salt flux in electrodialysis is independent of hydrodynamic conditions, including the variation of linear velocity and boundary layer condition. The salt flux is primarily proportional to the current density, the driving force of ion transport [51]. Therefore, the linear variation of the salt flux and electrical charge density can be utilized to predict mass transport under different operating conditions with the same IEMs and spacers installed in the electrodialysis stack.

In the pilot-scale testing, a baseline flow rate, namely, $1 \times$ flow rate of $7.5 \mathrm{gpm}$ $(28.4 \mathrm{~L} / \mathrm{min}$ product water), was chosen because of the same linear velocity as that in the bench-scale experiments at flow rate $1.5 \mathrm{~L} / \mathrm{min}$ (a linear velocity of $6.1 \mathrm{~cm} / \mathrm{s}$ ). Moreover, with $1 \times$ flow rate (baseline), $1.25 \times$ flow rate of $9.4 \mathrm{gpm}(35.5 \mathrm{~L} / \mathrm{min}$ product water), and $1.5 \times$ flow rate of $11.3 \mathrm{gpm}(42.6 \mathrm{~L} / \mathrm{min}$ product water), the flow rate conditions were investigated in the pilot-scale EDR system. The percent salt removal efficiency exhibited decreasing trends as the flow rate increased under the same current density (Figure 5a). The normalized salt removal indicated an overall positive impact of a higher flow rate at the starting operating conditions (Figure 5b). Unlike having a short residence time in the bench-scale testing ( $13 \mathrm{~s}$ vs. $9 \mathrm{~s}$ ), the residence time was $60 \mathrm{~s}, 48 \mathrm{~s}$, and $40 \mathrm{~s}$ corresponding to $1 \times, 1.25 \times$, and $1.5 \times$ flow rate, respectively. Salt ions in the diluate stream had a relatively long enough contact time to transport through IEMs, minimizing the influence of residence time on salt removal. The impact of a higher flow rate with increasing linear velocity demonstrated a dominant positive impact at initial current density tested in the pilot-scale electrodialysis, contrary to the overall negative effect of increased flow rate on desalination performance at low current density in the bench-scale system. Salt flux as a function of current density exhibited a single linear trend, regardless of the different flow rates in the pilot-scale testing (Figure 5c). The trend further confirmed the linear correlation of salt flux as a function of current density.

During electrodialysis of the reclaimed water, the bench-scale system achieved higher normalized salt removal of $6.10 \mathrm{~kg}$ salt $/ \mathrm{m}^{2}-\mathrm{kWh}$ at the current density of $2.6 \mathrm{~mA} / \mathrm{cm}^{2}$, while the pilot-scale system only achieved $0.08 \mathrm{~kg}$ salt $/ \mathrm{m}^{2}-\mathrm{kWh}$ at the current density of approximately $2.6 \mathrm{~mA} / \mathrm{cm}^{2}$ under the same linear velocity of $6.1 \mathrm{~cm} / \mathrm{s}$. The difference of normalized salt removal between the bench- and pilot-scale electrodialysis systems is attributed to the electrodialysis stack configuration and setup. The bench-scale unit has a smaller effective membrane area and a shorted flow path than the pilot system. This short flow path, combined with short hydraulic retention time (HRT), resulted in relatively smaller conductivity change between influents and effluents of diluate and concentrate chambers and reduced water splitting at the end of diluate stream, thus increasing desalination performance. This phenomenon was reported by another study using a different electrodialysis system (PCCell 640 02, PCCell GmbH, Germany) with a $64 \mathrm{~cm}^{2}$ effective membrane area of the same membrane type but different spacers [52]. A significantly higher normalized salt removal was observed in comparison with this study in treating solution with similar TDS $(\sim 1100 \mathrm{mg} / \mathrm{L})$ in bench-scale testing. This result was also confirmed in treating brackish groundwater, using the same bench- and pilot-scale electrodialysis systems as in this study [46]. 


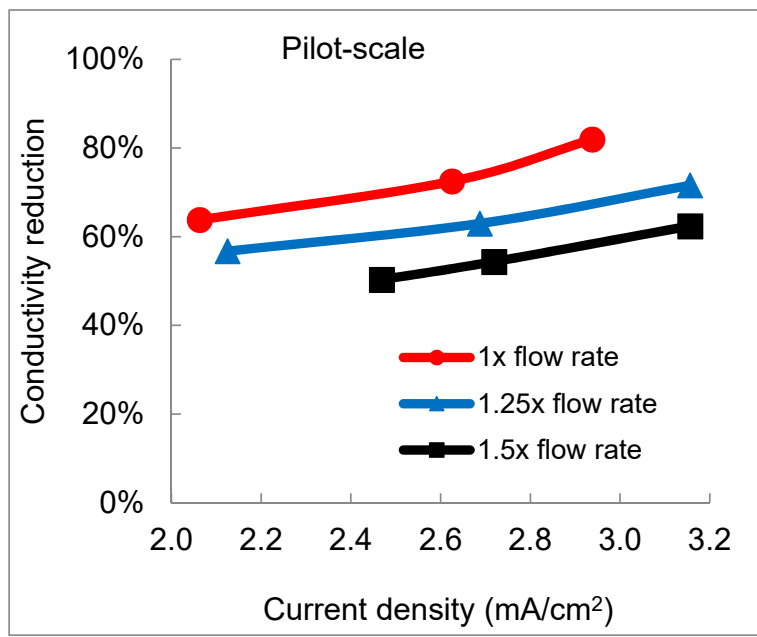

(a)

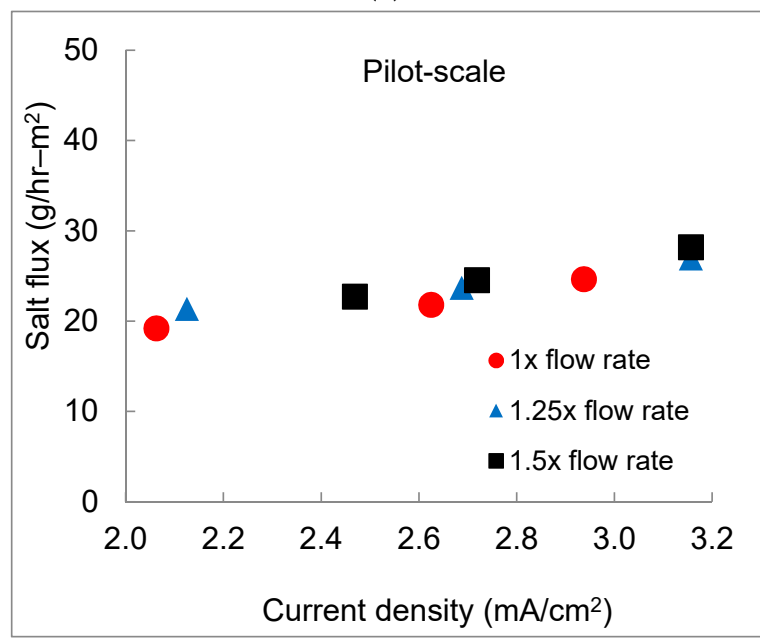

(c)

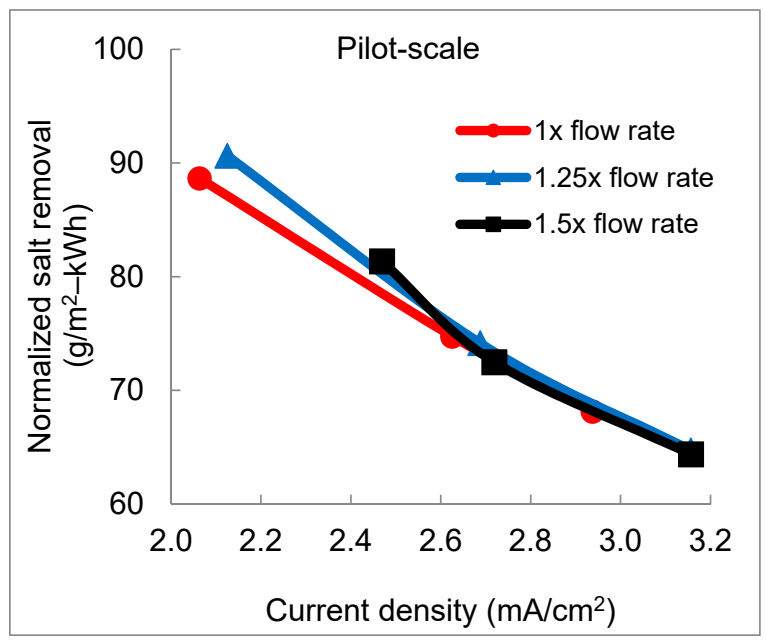

(b)

Figure 5. The effect of flow rate on desalination performance in the pilot-scale EDR system. (a) TDS reduction efficiency in terms of conductivity reduction; (b) normalized salt removal; and (c) salt flux through ion exchange membranes (IEMs).

As linearity of salt removal efficiency and salt flux found in both the bench- and pilot-scale experiments, the overall desalination performance from the bench- to pilotscale electrodialysis was expected to scale-up under the same hydraulic configurations (e.g., linear velocity, spacer pattern, and staging) [46]. With the same linear velocity of $6.1 \mathrm{~cm} / \mathrm{s}$, the desalination performance of the bench-scale and the $1^{\text {st }}$ electrical stage in the pilot-scale electrodialysis is evaluated in Figure 6. Generally, both systems exhibited similar trends with increasing current density. High-linear correlations between percent salt removal efficiency and current density (Figure 6a) were observed $\left(R^{2}>0.99\right)$ in the bench-scale and $1^{\text {st }}$ electrical stage of the pilot-scale system. The exhibited overlapping salt flux trends indicated the nearly identical normalized desalting capacity between the bench- and pilot-scale electrodialysis systems with scalable geometry and similar hydrodynamics (Figure 6b). It represented a high similarity in desalination performance, which can be utilized to evaluate the overall desalination of large-scale electrodialysis based on experiments of the scale-down bench-scale system. The desalination efficiency can be expressed as: 


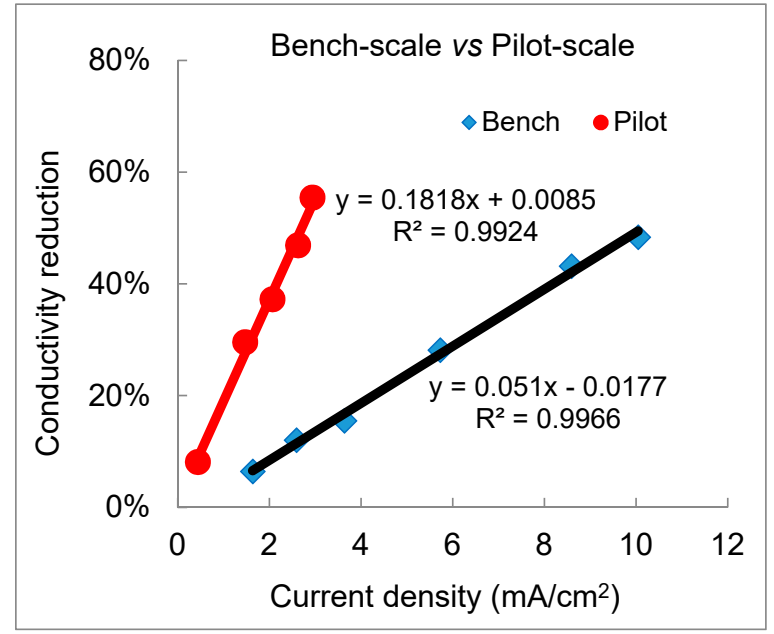

(a)

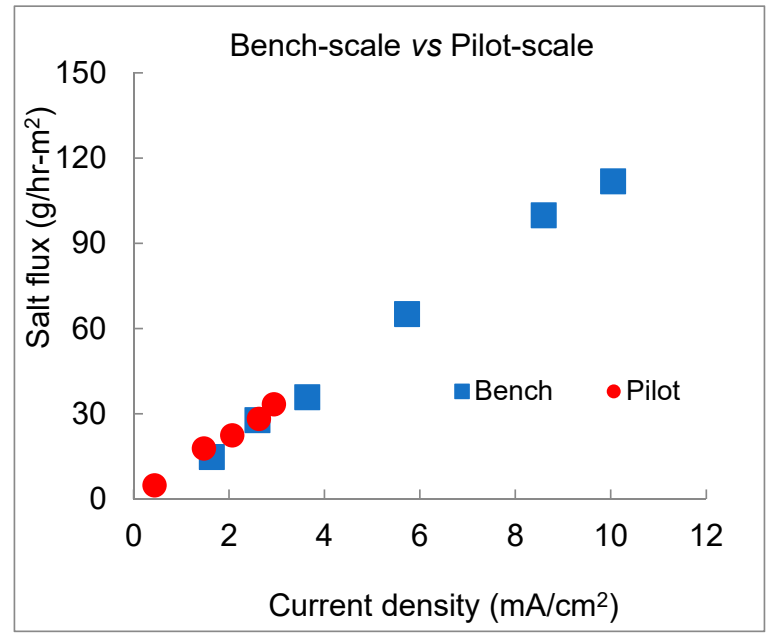

(b)

Figure 6. Scale-up of desalination performance from the bench- to pilot-scale electrodialysis of reclaimed water. (a) TDS removal in terms of conductivity reduction; (b) overall salt flux.

Conductivity reduction in pilot-scale system $=\alpha \times$ Conductivity reduction in benchscale unit $\times$ (Current Density pilot/Current Density bench) [46].

The ratio $\alpha$ was approximately 3.6 from Figure $6 a$, matching the ratio (3.4) of the residence time of pilot- over bench-scale experiments (HRT of $30 \mathrm{~s}$ over $9 \mathrm{~s}$ ). The consistency of high similarity between bench- and pilot-scale testing treating reclaimed water (TDS $1150 \mathrm{mg} / \mathrm{L}$, this study) and brackish groundwater (TDS $2700 \mathrm{mg} / \mathrm{L}$, our previous study) presented a reasonable accuracy in simulating pilot-scale electrodialysis system using bench-scale testing results.

\subsection{Impact of Applied Current Density on Desalination and Ion Separation}

Concentration polarization with increased current density has a significant impact on the desalination performance of electrodialysis and EDR systems [53]. To determine the current density that ensures meeting the required standards of target ions (i.e., $\mathrm{Na}^{+}<110 \mathrm{mg} / \mathrm{L}$, $\mathrm{Cl}^{-}<150 \mathrm{mg} / \mathrm{L}$ ), the pilot-scale EDR system was operated at several current densities for treating the reclaimed water at the baseline flow rate of $7.5 \mathrm{gpm}(28.4 \mathrm{~L} / \mathrm{min}$ product water, or $6.1 \mathrm{~cm} / \mathrm{s}$ ). Table 1 summarizes the corresponding parameters of the $1^{\text {st }}$ and 2 nd electrical stages in the EDR pilot-scale system.

With increasing applied voltage and current density, the salt removal efficiency increased, coupling with the increased flux of different ions and reduced salt concentration in the product water. The overall percent salt removal efficiency increased from $45 \%$ (Case\#1) to $82 \%$ (Case\#4). Meanwhile, the highest percent TDS reduction efficiency of any single hydraulic stage was below $60 \%$ at the four cases tested, within the typical optimal design range of commercial EDR system [54]. The sodium concentration in the product water decreased from $194 \mathrm{mg} / \mathrm{L}$ to $126 \mathrm{mg} / \mathrm{L}$ from Case\#1 to Case\#2. The chloride concentration dropped to $101 \mathrm{mg} / \mathrm{L}$ in the product water of Case\#2, meeting the required goal $(<150 \mathrm{mg} / \mathrm{L})$, while the sodium concentration was $97 \mathrm{mg} / \mathrm{L}$ in Case\#3. Using the correlation of current density and salt concentration in the WATSYS ${ }^{\mathrm{TM}}$ program, the goal of sodium concentration $110 \mathrm{mg} / \mathrm{L}$ in the product water can be met at the current density of $2.36 \mathrm{~mA} / \mathrm{cm}^{2}$ for the $1^{\text {st }}$ electrical stage and $1.5 \mathrm{~mA} / \mathrm{cm}^{2}$ for the $2^{\text {nd }}$ electrical stage. In contrast, chloride concentration in product water was significantly below the requirement $(<100 \mathrm{mg} / \mathrm{L})$. Therefore, the pilot-scale EDR system using the normal grade membranes can meet the sodium and chloride water quality goals of treating reclaimed water for golf course irrigation and surface discharge. The normalized salt mass removal exhibited a decreasing trend with the increase of current density, e.g., $0.12 \mathrm{~kg}$ salt $/ \mathrm{m}^{2}-\mathrm{kWh}$ to $0.07 \mathrm{~kg}$ 
salt $/ \mathrm{m}^{2}-\mathrm{kWh}$ from Case\#1 to Case\#4, revealing reduced energy efficiency when operating at higher current density.

Table 1. Summary of operational parameters and data in different cases.

\begin{tabular}{ccccccccc}
\hline Parameters & \multicolumn{2}{c}{ Case\#1(C\#1) } & \multicolumn{2}{c}{ Case\#2(C\#2) } & \multicolumn{2}{c}{ Case\#3(C\#3) } & \multicolumn{2}{c}{ Case\#4(C\#4) } \\
\hline Electrical Stage & $1^{\text {st }}$ & $2^{\text {nd }}$ & $1^{\text {st }}$ & $2^{\text {nd }}$ & $1^{\text {st }}$ & $2^{\text {nd }}$ & $1^{\text {st }}$ & $2^{\text {nd }}$ \\
Voltage, $(\mathrm{V})$ & 14 & 13 & 19 & 19 & 23 & 21 & 26 & 24 \\
Current, (A) & 4.7 & 3.6 & 6.7 & 4.8 & 8.3 & 4.8 & 9.5 & 4.9 \\
Current Density, $(\mathrm{mA} / \mathrm{cm})^{2}$ & 1.5 & 1.1 & 2.1 & 1.5 & 2.6 & 1.5 & 3.0 & 1.5 \\
Salt Removal, $(\%)$ & $29.6 \%$ & $22.3 \%$ & $37.3 \%$ & $42.2 \%$ & $46.9 \%$ & $48.1 \%$ & $55.5 \%$ & $59.4 \%$ \\
Salt Removal Rate, (g/hr) & 571 & 302 & 719 & 510 & 904 & 492 & 1070 & 509 \\
Energy Consumption, $(\mathrm{kWh})$ & 65.8 & 46.8 & 127.3 & 91.2 & 193.2 & 98.7 & 244.4 & 117.6 \\
Energy Consumption, $(\mathrm{kWh} / \mathrm{kg}$ salt) & 0.12 & 0.15 & 0.18 & 0.18 & 0.21 & 0.20 & 0.23 & 0.23 \\
$\mathrm{Na}^{+},(\mathrm{mg} / \mathrm{L})$ & 244 & 194 & 204 & 126 & 191 & 97 & 169 & 75 \\
$\mathrm{Cl}^{-},(\mathrm{mg} / \mathrm{L})$ & 279 & 205 & 204 & 101 & 171 & 72 & 147 & 50 \\
\hline
\end{tabular}

The specific ion transport is depicted in Figure 7. In Case\#1, the flux of calcium was dominant, reaching $191 \mathrm{meq} / \mathrm{hr}-\mathrm{m}^{2}$ compared to $139 \mathrm{meq} / \mathrm{hr}-\mathrm{m}^{2}$ for sodium (Figure $7 \mathrm{a}$ ), even though the ratio of equivalent concentration of calcium over sodium was less than 0.4 in the feedwater. Selective transport of magnesium over sodium was also noticed, considering the lower ratio of equivalent concentration of magnesium over sodium in the feedwater (approximately 0.2). The selective transport of divalent cations (e.g., $\mathrm{Ca}^{2+}$ and $\mathrm{Mg}^{2+}$ ) over monovalent cation $\left(\mathrm{Na}^{+}\right)$was mainly attributed to the higher electrostatic attraction between the CEMs and the divalent ions with two charges, in comparison to monovalent cation with one charge [46]. For instance, the percent removal efficiency of calcium and magnesium reached $84 \%$ and $83 \%$ at Case\#1 with low current density, respectively, while removal efficiency of $24 \%$ and $39 \%$ were recorded for sodium and potassium, respectively. Enhanced transport of divalent anion $\left(\mathrm{SO}_{4}{ }^{2-}\right)$ was also detected $\left(195 \mathrm{meq} / \mathrm{hr}-\mathrm{m}^{2}\right)$ over monovalent anion (262 meq/hr- $\mathrm{m}^{2}$ for $\mathrm{Cl}^{-}$) in Figure $7 \mathrm{~b}$, in respective to less than 0.5 of equivalent concentration ratio of sulfate over chloride in the feedwater. With increasing current density, the increase of salt removal was mostly carried out by the transport of monovalent ions. The flux of monovalent ions increased linearly with the increase of current density, while divalent ions displayed a non-linearity trend.

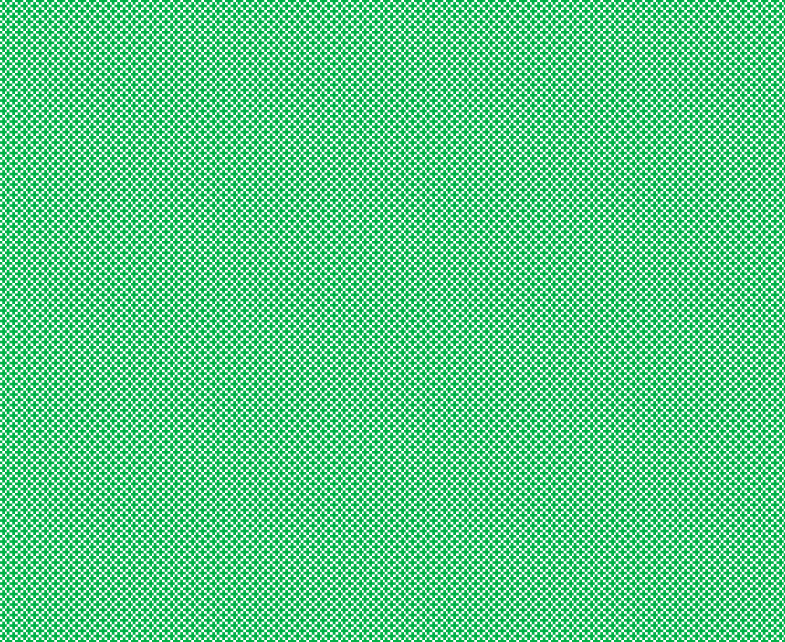

(a)

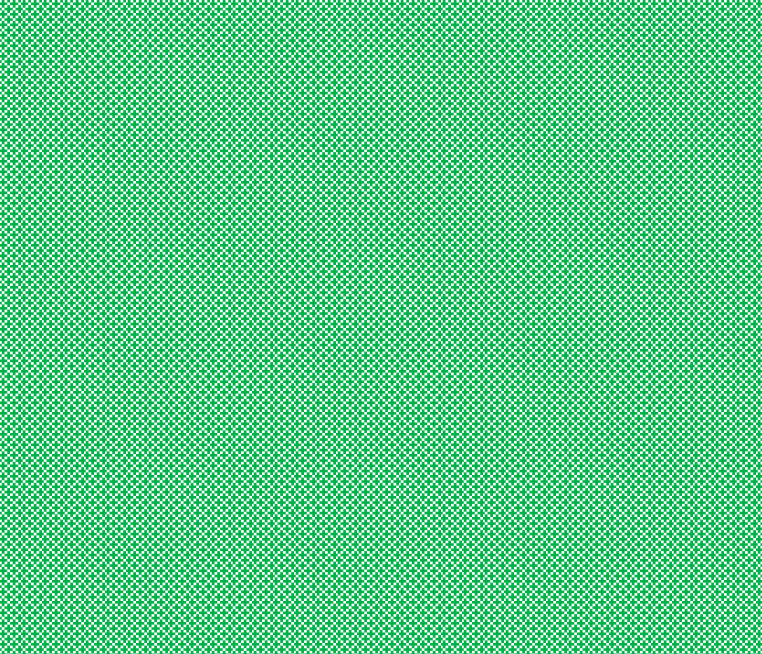

(b)

Figure 7. Ion transport in the pilot-scale EDR for treating the reclaimed water at $50 \%$ water recovery and baseline flow rates. (a) Ion flux of major cations; and (b) ion flux of major anions. 
Selective separation of divalent ions vs. monovalent ions was studied based on $\mathrm{Na}$ selectivity for cations and $\mathrm{Cl}$ selectivity for anions, defined as relative transport number (RTN, Equation (6) in Supplemental Information). The RTN calculation is based on the widely-adopted equation developed by Sata et al. [55]. $\mathrm{Na}^{+}$was specified as the reference cation, and $\mathrm{Cl}^{-}$was chosen to be the reference anion. The RTN is measured as the amount of a given ion removed (in meq) divided by its arithmetic average equivalent concentration of initial and final concentration in the diluate streams, as opposed to the amount of reference ion removed (in meq) divided by the average arithmetic equivalent the reference ion concentration of initial and final concentration.

The trend of the RTN value of calcium was similar to that of magnesium, indicating similar transport behavior for the major divalent cations. Divalent ions were selectively transported over monovalent ions $(\mathrm{RTN}>1)$ in the entire current density range tested. The elevated removal of divalent ions was pronounced at low current density, i.e., the maximum RTN value of 5.5 for calcium (Figure 8a). The downtrend of RTN for both divalent cation and anion was attributed to the sharp concentration gradient in the boundary layer as current density increased, enhancing the transport of monovalent ions in the boundary layer because of higher diffusivity of monovalent over divalent ions [56] and the downshifted degree of increment for divalent removal with the increase of current density (Figure 7). Furthermore, the total flux of monovalent ions increased linearly with the increase of current density, while the overall flux of divalent ions fluctuated in a relatively narrow range around $500 \mathrm{meq} / \mathrm{hr}-\mathrm{m}^{2}$ (Figure $8 \mathrm{~b}$ ).

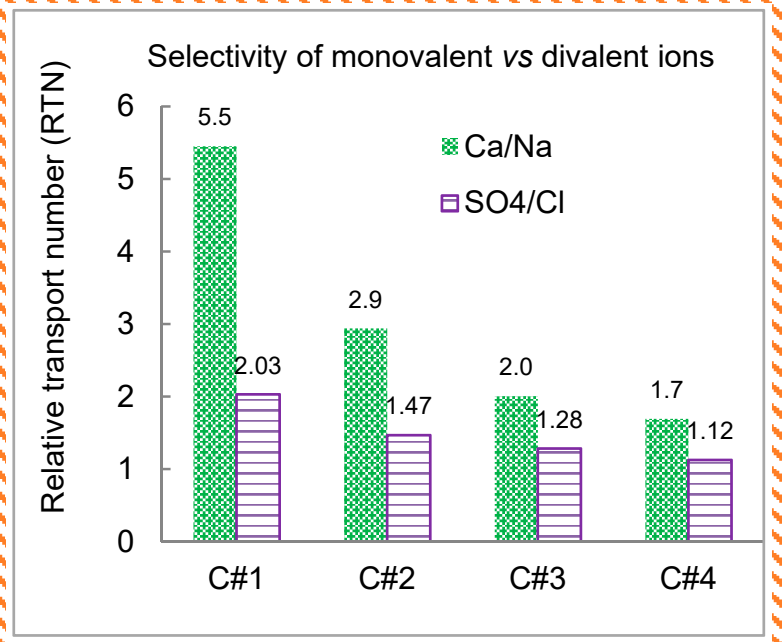

(a)

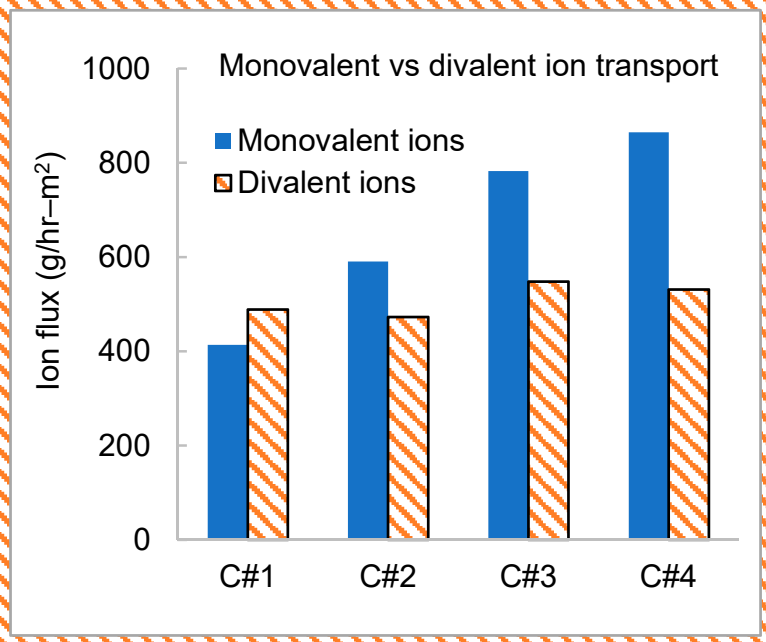

(b)

Figure 8. Selectivity of monovalent vs. divalent ion (a) relative transport number of calcium over sodium and sulfate over chloride; and (b) ion flux of monovalent over divalent ions.

Comparison between the measured individual ion concentration data and the projection results using the WATSYS ${ }^{\mathrm{TM}}$ program was investigated (Figure S1 in Supplemental Information). The WATSYS ${ }^{\mathrm{TM}}$ program projected well the overall salt removal in terms of conductivity reduction and $\mathrm{pH}$ change. However, there were discrepancies between the measured ion concentrations and the projection results. The program also projected fairly well the transport of monovalent ions, while for divalent ions (e.g., $\mathrm{Ca}^{2+}, \mathrm{Mg}^{2+}$, and $\mathrm{SO}_{4}{ }^{2-}$ ), the differences between projected and measured data were in the range of $10-40 \%$. The monovalent ions demonstrated a fairly linear correlation between current density and ion flux, while non-linearity was noticed in divalent ions separation (Figure 8b). The nonlinear trend of divalent ions might contribute to the discrepancies between the measured and the WATSYS ${ }^{\mathrm{TM}}$ projected removal data.

A low concentration of organic matter existed in the reclaimed water, measured as TOC of $7.7 \pm 0.2 \mathrm{mg} / \mathrm{L}$. The TOC concentration in product water ranged from $7.2 \mathrm{mg} / \mathrm{L}$ to 
$7.6 \mathrm{mg} / \mathrm{L}$ in the bench-scale electrodialysis system. One product water from Case\#1 was measured as $5.03 \mathrm{mg} / \mathrm{L}$ of TOC. It was reported that organic matter in the reclaimed water is mostly neutral substances, which would not migrate under electric field [57]. Therefore, organic removal was not further discussed in this study because there was no significant decrease of TOC in product water using electrodialysis.

\subsection{Effect of Water Recovery}

The salt reduction decreased with the increase of water recovery in the pilot-scale EDR system due to a higher concentration gradient between the diluate and concentrate streams. The variation of conductivity reduction was less than $15 \%$ when the water recovery increased from $50 \%$ to $80 \%$. The concentration of individual ion increased in product water as the water recovery increased (Figure 9a). The $\mathrm{pH}$ of product waters at different water recovery was closely matching $(\mathrm{pH}$ 7.0-7.1). The variations of percent removal of the major cations were within $2 \%$ as water recovery ranging from $50 \%$ to $70 \%$, except a sharp drop at water recovery of $80 \%$ (Figure $9 \mathrm{~b}$ ). The transport of chloride was relatively more sensitive to water recovery compared to other major ions. The highest equivalent concentration of chloride in concentrate might restrain the chloride transport from the diluate to concentrate stream.

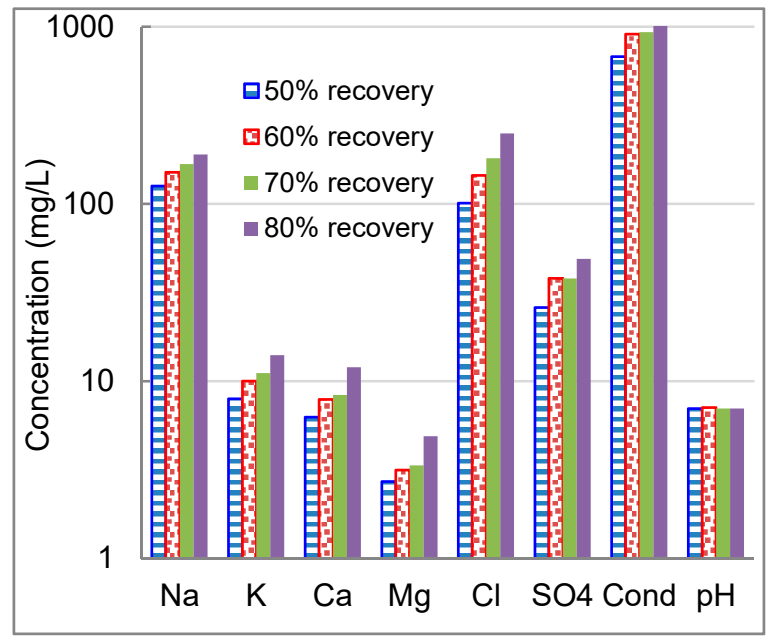

(a)

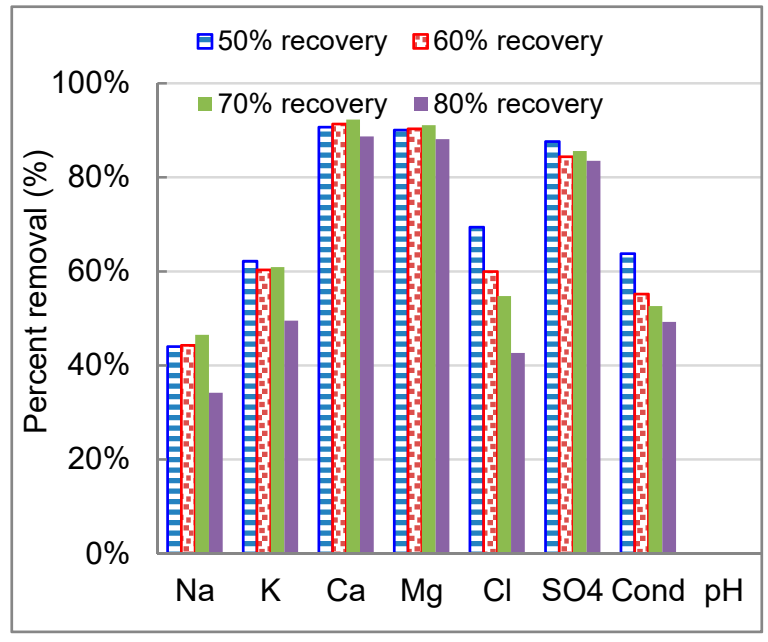

(b)

Figure 9. Salt rejection as a function of water recovery in treating reclaimed water (a) water quality in product water; (b) percentage removal of conductivity and major ions.

The selective separation of divalent ions vs. monovalent ions is presented in Figure 10. For cations, the RTN value (2.8-3.0) was relatively stable when the water recovery increased from $50 \%$ to $70 \%$, while a sharp increase to $3.9(\sim 40 \%$ increase) at water recovery of $80 \%$. Stronger back diffusion potential of monovalent cations from the concentrate streams contributed to the enhanced divalent cation selectivity at higher water recovery. However, the RTN value of sulfate steadily increased from 1.47 to 1.99 as water recovery increased from $50 \%$ to $70 \%$, then jumped to 2.64 at water recovery of $80 \%$. 


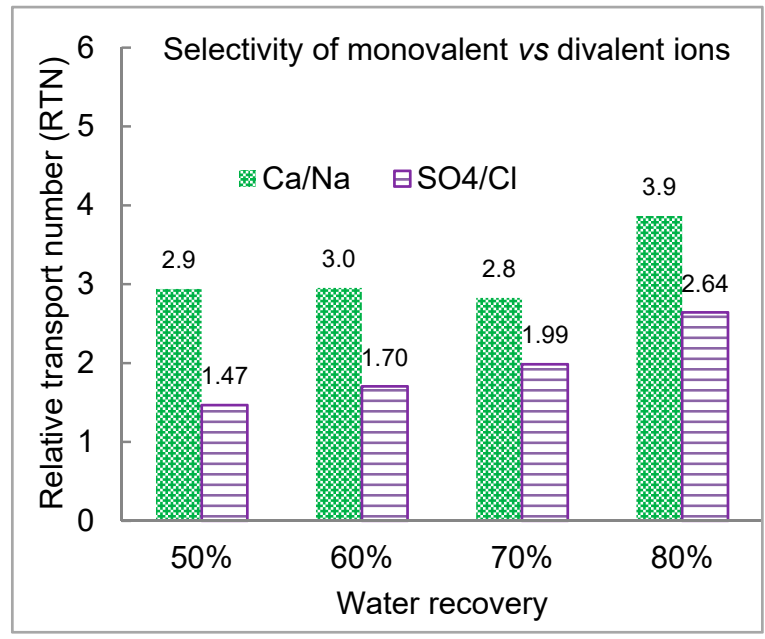

(a)

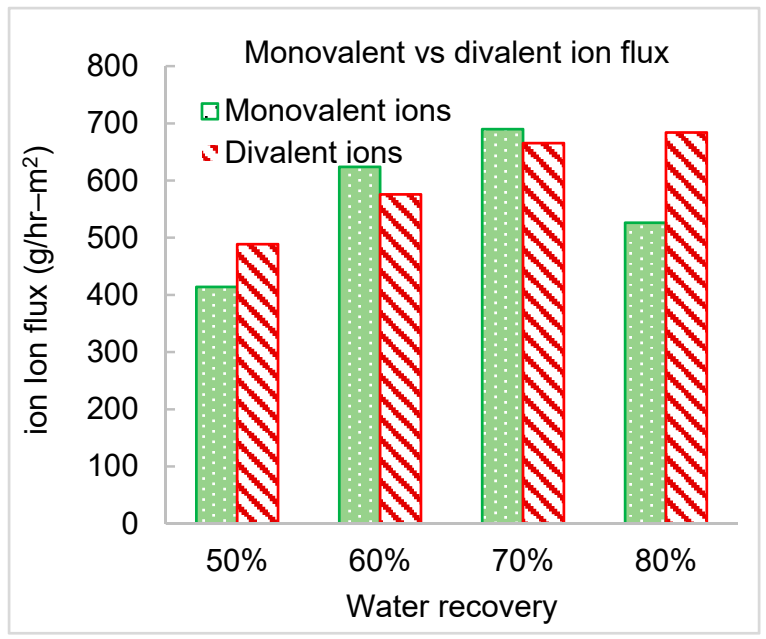

(b)

Figure 10. Selectivity of monovalent vs. divalent ion as a function of water recovery. (a) Relative transport number; and (b) ion flux of monovalent over divalent ions.

After finishing all the experiments, minor inorganic scaling was spotted on the CEM surface, while no scalants were observed on the AEM surface by comparing the used and pristine membranes.

\subsection{Techno-Economic Analysis}

Based on the testing results, alternative treatment configurations were developed in comparison to the existing UF/RO system in Scottsdale Water Campus as baseline. The blending analysis (Table 2) and cost comparison (Table 3) were presented for a one million gallon per day $\left(\mathrm{mgd}\right.$, or $3785 \mathrm{~m}^{3} / \mathrm{d}$ ) feed water flow on a realistic and common basis. Cost evaluation was performed in accordance with the Association for the Advancement of Cost Engineering (AACE) [58]. A detailed cost comparison was developed to evaluate the total capital cost, annual operation and maintenance (O\&M) cost, and 20-year life cycle cost for the proposed treatment alternatives (Detailed assumptions in Supplemental Information). Tables 2 and 3 summarize the calculated costs and system configuration and performance for the UF/RO system as well as the 2-stage EDR and 4-stage EDR design based on WATSYS ${ }^{\mathrm{TM}}$ simulation and pilot testing results.

Table 2. Blending analysis comparison between EDR and baseline.

\begin{tabular}{|c|c|c|c|c|c|}
\hline \multirow{2}{*}{ Parameters } & \multirow{2}{*}{$\begin{array}{l}\text { Baseline } \\
\text { (UF/RO) }\end{array}$} & \multicolumn{2}{|c|}{ 2-Stage EDR } & \multicolumn{2}{|c|}{ 4-Stage EDR } \\
\hline & & $\begin{array}{c}\text { EDR } \\
\text { (WATSYS) }\end{array}$ & $\begin{array}{c}\text { EDR } \\
\text { (Testing) }\end{array}$ & $\begin{array}{c}\text { EDR } \\
\text { (WATSYS) }\end{array}$ & $\begin{array}{c}\text { EDR } \\
\text { (Testing) }\end{array}$ \\
\hline Feed Water Flow (mgd) & 1 & 1 & 1 & 1 & 1 \\
\hline Feed Water $\mathrm{Na}(\mathrm{mg} / \mathrm{L})$ & 235 & 235 & 235 & 235 & 235 \\
\hline \% Flow Treated & $60.5 \%$ & $69.0 \%$ & $100.0 \%$ & $69.0 \%$ & $78.0 \%$ \\
\hline Overall Recovery & $88 \%$ & $93 \%$ & $92 \%$ & $93 \%$ & $92 \%$ \\
\hline Unit Recovery & $85 \%$ & $90 \%$ & $90 \%$ & $90 \%$ & $90 \%$ \\
\hline Blended Water Flow (mgd) & 0.88 & 0.93 & 0.92 & 0.93 & 0.92 \\
\hline Product Water $\mathrm{Na}(\mathrm{mg} / \mathrm{L})$ & 110 & 110 & 129 & 110 & 110 \\
\hline Product TDS $(\mathrm{mg} / \mathrm{L})$ & 530 & 522 & 489 & 522 & 433 \\
\hline Concentrate Flow (gpm) & 60 & 48 & 69 & 48 & 54 \\
\hline Concentrate TDS (mg/L) & 7530 & 9662 & 7130 & 9662 & 9662 \\
\hline Concentrate $\mathrm{Na}(\mathrm{mg} / \mathrm{L})$ & 1524 & 2136 & 1715 & 1927 & 1715 \\
\hline Number of Product Line & - & 7 & 8 & 7 & 6 \\
\hline Number of Stages & - & 2 & 2 & 4 & 4 \\
\hline
\end{tabular}


Table 3. Cost comparison between EDR and baseline.

\begin{tabular}{|c|c|c|c|c|c|}
\hline \multirow{2}{*}{ Parameters } & \multirow{2}{*}{ Baseline (UF/RO) } & \multicolumn{2}{|c|}{ 2-Stage EDR } & \multicolumn{2}{|c|}{ 4-Stage EDR } \\
\hline & & EDR (WATSYS) & EDR (Testing) & EDR (WATSYS) & EDR (Testing) \\
\hline UF & $\$ 599,000$ & \$- & $\$-$ & $\$-$ & \$- \\
\hline Residuals Handling & $\$ 765,000$ & \$- & $\$-$ & $\$-$ & \$- \\
\hline $\mathrm{RO}$ & $\$ 889,000$ & $\$-$ & $\$-$ & $\$-$ & \$- \\
\hline EDR & $\$-$ & $\$ 1,820,000$ & $\$ 2,080,000$ & $\$ 2,520,000$ & $\$ 2,940,000$ \\
\hline Building & $\$ 652,000$ & $\$ 435,000$ & $\$ 435,000$ & $\$ 435,000$ & $\$ 435,000$ \\
\hline Civil Site Works (5\%) & $\$ 146,000$ & $\$ 113,000$ & $\$ 126,000$ & $\$ 148,000$ & $\$ 169,000$ \\
\hline Electrical and I\&C (25\%) & $\$ 726,000$ & $\$ 564,000$ & $\$ 629,000$ & $\$ 739,000$ & $\$ 844,000$ \\
\hline Contingency $(30 \%)$ & $\$ 1,189,000$ & $\$ 924,000$ & $\$ 1,030,000$ & $\$ 1,210,000$ & $\$ 1,382,000$ \\
\hline \multicolumn{6}{|l|}{ General Conditions: } \\
\hline Mobilization \& & $\$ 189,000$ & $\$ 147,000$ & $\$ 164,000$ & $\$ 193,000$ & $\$ 220,000$ \\
\hline \multicolumn{6}{|l|}{ Demobilization (5\%) } \\
\hline \multicolumn{6}{|l|}{ Engineering, } \\
\hline $\begin{array}{c}\text { Administration, and Legal } \\
\qquad(18 \%)\end{array}$ & $\$ 928,000$ & $\$ 721,000$ & $\$ 804,000$ & $\$ 944,000$ & $\$ 1,078,000$ \\
\hline Total Capital Costs $(\$)$ & $6,081,000$ & $4,721,000$ & $5,266,000$ & $6,187,000$ & $7,066,000$ \\
\hline $\begin{array}{l}\text { Unit Capital Costs } \\
\qquad(\$ / g p d)\end{array}$ & 6.88 & 5.05 & 5.72 & 6.64 & 7.68 \\
\hline Total Power Cost (\$/year) & 84,000 & 28,000 & 20,000 & 44,000 & 28,000 \\
\hline $\begin{array}{c}\text { Total Chemical Cost } \\
\text { (\$/year) }\end{array}$ & 69,000 & 67,000 & 67,000 & 67,000 & 67,000 \\
\hline Total Labor Cost (\$/year) & 126,000 & 126,000 & 126,000 & 126,000 & 126,000 \\
\hline $\begin{array}{c}\text { Total Replacement Cost } \\
\text { (\$/year) }\end{array}$ & 17,000 & 14,000 & 13,000 & 14,000 & 13,000 \\
\hline Contingency $(20 \%)$ & 59,000 & 47,000 & 45,000 & 50,000 & 47,000 \\
\hline Total O\&M Costs & 353,000 & 280,000 & 269,000 & 299,000 & 278,000 \\
\hline Unit O\&M Costs $(\$ / \mathrm{kgal})$ & 1.09 & 0.82 & 0.80 & 0.88 & 0.83 \\
\hline Total Life Cycle Costs (\$) & $12,800,000$ & $10,100,000$ & $10,400,000$ & $11,900,000$ & $12,400,000$ \\
\hline
\end{tabular}

The estimated treatment costs of the electrodialysis processes were proven lower than using UF/RO to treat reclaimed water for golf course irrigation. The economic evaluation based on the WATSYS ${ }^{\mathrm{TM}}$ data revealed a more than $21 \%$ total cost reduction while satisfying the product water quality requirements (shown in Tables 2 and 3). The total life cycle cost was reduced by approximately $19 \%$ using 2-stage EDR system based on the testing data. The chloride concentration was below the target goal of $150 \mathrm{mg} / \mathrm{L}$. However, the sodium concentration cannot meet the operating goal of $110 \mathrm{mg} / \mathrm{L}$, though very close to the contractual goal of $125 \mathrm{mg} / \mathrm{L}$ based on the pilot-scale testing results. Therefore a 4-stage EDR system was designed to meet both water quality requirements for sodium of $110 \mathrm{mg} / \mathrm{L}$ and chloride of $150 \mathrm{mg} / \mathrm{L}$ as well as to reduce the costs for treating reclaimed water for golf course irrigation. For a 4-stage EDR system, the unit O\&M cost would be reduced to $\$ 0.83 / \mathrm{kgal}\left(\$ 0.22 / \mathrm{m}^{3}\right)$ from $\$ 1.09 / \mathrm{kgal}\left(\$ 0.29 / \mathrm{m}^{3}\right)$ in the baseline condition. The total life cycle cost was reduced to $\$ 11,900,000$ and $\$ 12,400,000$ in the WATSYS ${ }^{\text {TM }}$ simulation and evaluation based on the testing data, respectively, in comparison to $\$ 12,800,000$ in the $\mathrm{UF} / \mathrm{RO}$ baseline.

In addition to the reduced treatment costs, the EDR system has the advantage of achieving high water recovery: $90 \%$ unit water recovery and $92-93 \%$ overall water recovery considering water blending, while the UF/RO system could only achieve $85 \%$ unit water recovery and $88 \%$ overall water recovery. The TDS concentration of the product water of the EDR system is estimated better than the RO system: $433 \mathrm{mg} / \mathrm{L}$ for the 4-stage EDR system vs. $530 \mathrm{mg} / \mathrm{L}$ for UF/RO.

In summary, the techno-economic modeling indicates that using electrodialysis for treating reclaimed water is more cost-effective and can recover more water than the $\mathrm{RO}$ process. 


\section{Conclusions}

In this study, bench- and pilot-scale electrodialysis experiments were conducted to assess the technical feasibility and economic viability of reclaimed water desalination. The study elucidated the effects of various operating conditions, such as flow rate, HRT, applied current density, staging, and water recovery, on overall salt removal and monovalent permselectivity during reclaimed water treatment using electrodialysis.

The overall negative impact of a higher flow rate was observed at the current density below $5.6 \mathrm{~mA} / \mathrm{cm}^{2}$ for the bench-scale experiments. In comparison, the impact of a higher flow rate with increased linear velocity demonstrated a dominant positive impact at the initial current density tested in the pilot-scale electrodialysis. The linear trend of salt removal efficiency and salt flux was observed in both bench- and pilot-scale experiments, with overlapping linear trends of salt flux and scalable desalination efficiency (matching the ratio of residence time) between the bench- and pilot-scale electrodialysis systems. Such linear correlation of the salt flux and electrical charge density can be utilized to predict solute mass transport under different operating conditions with the same IEMs and spacers installed in the electrodialysis stack.

The pilot-scale EDR system using the normal grade membranes demonstrated the technical feasibility of treating reclaimed water for golf course irrigation and surface discharge. An increase in the applied voltage enhanced the removal efficiency of ion separation and reduced the salt content in the product water. The target goal of sodium concentration $110 \mathrm{mg} / \mathrm{L}$ in the product water can be met at the current density of $2.36 \mathrm{~mA} / \mathrm{cm}^{2}$ for the $1^{\text {st }}$ electrical stage and $1.5 \mathrm{~mA} / \mathrm{cm}^{2}$ for the $2^{\text {nd }}$ electrical stage, while chloride concentration in product water was significantly below the requirement $(<100 \mathrm{mg} / \mathrm{L})$. Monovalentselectivity in terms of equivalent removal of divalent ions $\left(\mathrm{Ca}^{2+}, \mathrm{Mg}^{2+}\right.$, and $\left.\mathrm{SO}_{4}{ }^{2-}\right)$ over monovalent ions $\left(\mathrm{Na}^{+}, \mathrm{Cl}^{-}\right)$was affected by both current density and water recovery. The salt rejection decreased in the pilot-scale EDR system at higher water recovery, due to a higher concentration gradient between the diluate and concentrate streams. No significant scaling/fouling on the IEM surface in the pilot-scale electrodialysis system was observed throughout the three-month continuous testing period.

Total cost reduction can be achieved in electrodialysis, compared to the existing treatment option. The unit O\&M cost would be reduced to $\$ 0.83 / \mathrm{kgal}\left(\$ 0.22 / \mathrm{m}^{3}\right)$ from $\$ 1.09 / \mathrm{kgal}\left(\$ 0.29 / \mathrm{m}^{3}\right)$ in the baseline condition, along with reduced total life cycle cost. The water recovery of the EDR system is higher than the UF/RO, with $90 \%$ unit water recovery and $92-93 \%$ overall water recovery. In conclusion, the electrodialysis demonstrated promising technical feasibility and economic viability for treating reclaimed water.

Supplementary Materials: The following are available online at https://www.mdpi.com/article/10 $.3390 /$ membranes11050333/s1. Figure S1. Desalination performance as a function of current density in terms of ion concentration, ion removal, conductivity, conductivity reduction, and $\mathrm{pH}$ change. Reference [58] is cited in supplementary material.

Author Contributions: Conceptualization, X.X., Q.H., G.M., H.W., N.N. and P.X.; methodology, X.X., Q.H., G.M., H.W., N.N. and P.X.; data analysis and visualizations, X.X., Q.H., G.M., H.W. and P.X.; writing—original draft preparation, X.X., Q.H.; writing—review and editing, X.X. and P.X.; supervision, H.W. and P.X.; project administration, N.N. and P.X.; funding acquisition, N.N. and P.X. All authors have read and agreed to the published version of the manuscript.

Funding: This research was funded by the U.S. Department of the Interior, Bureau of Reclamation (R14AP00175), and the National Science Foundation Engineering Research Center ReNUWIt (EEC-1028968).

Institutional Review Board Statement: Not applicable.

Informed Consent Statement: Not applicable.

Data Availability Statement: Detailed experimental data can be provided upon reasonable request. 
Acknowledgments: The authors thank Patrick Girvin, Danny Jorgensen, Yongchang Zheng, John Barber, and Ken Irwin with Suez Water Technologies \& Solutions for technical support of the electrodialysis systems; and Art Nunez, Laura McCasland, and Suzanne Grendahl for supporting the pilot-scale testing and assistance in chemical analysis in the Scottsdale Water Campus, AZ.

Conflicts of Interest: The authors declare no conflict of interest.

\section{References}

1. Greve, P.; Kahil, T.; Mochizuki, J.; Schinko, T.; Satoh, Y.; Burek, P.; Fischer, G.; Tramberend, S.; Burtscher, R.; Langan, S.; et al. Global assessment of water challenges under uncertainty in water scarcity projections. Nat. Sustain. 2018, 1, 486-494. [CrossRef]

2. Nobre, R.L.G.; Caliman, A.; Cabral, C.R.; de Carvalho Araújo, F.; Guerin, J.; Dantas, F.D.C.C.; Quesado, L.B.; Venticinque, E.M.; Guariento, R.D.; Amado, A.M.; et al. Precipitation, landscape properties and land use interactively affect water quality of tropical freshwaters. Sci. Total Environ. 2020, 716, 137044. [CrossRef]

3. MacDonald, G.M. Water, climate change, and sustainability in the southwest. Proc. Natl. Acad. Sci. USA 2010, 107, 21256-21262. [CrossRef]

4. $\quad$ Pettygrove, G.S. Irrigation with Reclaimed Municipal Wastewater-A Guidance Manual; CRC Press: Boca Raton, FL, USA, 2018.

5. Zhang, Y.; Shen, Y. Wastewater irrigation: Past, present, and future. Wiley Interdiscip. Rev. Water 2019, 6, e1234. [CrossRef]

6. Fournier, E.D.; Keller, A.A.; Geyer, R.; Frew, J. Investigating the energy-water usage efficiency of the reuse of treated municipal wastewater for artificial groundwater recharge. Environ. Sci. Technol. 2016, 50, 2044-2053. [CrossRef] [PubMed]

7. Zuurbier, K.; Smeets, P.; Roest, K.; van Vierssen, W. Use of Wastewater in Managed Aquifer Recharge for Agricultural and Drinking Purposes: The Dutch Experience. In Safe Use of Wastewater in Agriculture; Springer: New York, NY, USA, 2018; pp. 159-175.

8. Wei, X.; Binger, Z.M.; Achilli, A.; Sanders, K.T.; Childress, A.E. A modeling framework to evaluate blending of seawater and treated wastewater streams for synergistic desalination and potable reuse. Water Res. 2020, 170, 115282. [CrossRef] [PubMed]

9. Walker, M.E.; Theregowda, R.B.; Safari, I.; Abbasian, J.; Arastoopour, H.; Dzombak, D.A.; Hsieh, M.K.; Miller, D.C. Utilization of municipal wastewater for cooling in thermoelectric power plants: Evaluation of the combined cost of makeup water treatment and increased condenser fouling. Energy 2013, 60, 139-147. [CrossRef]

10. Council, N.R. Water Reuse: Potential for Expanding the Nation's Water Supply through Reuse of Municipal Wastewater; National Academies Press: Washington, DC, USA, 2012.

11. Evanylo, G.; Ervin, E.; Zhang, X. Reclaimed water for turfgrass irrigation. Water 2010, 2, 685-701. [CrossRef]

12. Phogat, V.; Mallants, D.; Cox, J.W.; Šimůnek, J.; Oliver, D.P.; Pitt, T.; Petrie, P.R. Impact of long-term recycled water irrigation on crop yield and soil chemical properties. Agric. Water Manag. 2020, 237, 106167. [CrossRef]

13. Qian, Y.; Mecham, B. Long-term effects of recycled wastewater irrigation on soil chemical properties on golf course fairways. Agron. J. 2005, 97, 717-721. [CrossRef]

14. Suarez, D.L.; Wood, J.D.; Lesch, S.M. Infiltration into cropped soils: Effect of rain and sodium adsorption ratio-impacted irrigation water. J. Environ. Qual. 2008, 37 (Suppl. S5), S-169-S-179. [CrossRef]

15. Goodfellow, W.L.; Ausley, L.W.; Burton, D.T.; Denton, D.L.; Dorn, P.B.; Grothe, D.R.; Heber, M.A.; Norberg-King, T.J.; Rodgers, J.H., Jr. Major ion toxicity in effluents: A review with permitting recommendations. Environ. Toxicol. Chem. Int. J. 2000, 19, 175-182. [CrossRef]

16. Pype, M.-L.; Lawrence, M.G.; Keller, J.; Gernjak, W. Reverse osmosis integrity monitoring in water reuse: The challenge to verify virus removal-A review. Water Res. 2016, 98, 384-395. [CrossRef]

17. Qasim, M.; Badrelzaman, M.; Darwish, N.N.; Darwish, N.A.; Hilal, N. Reverse osmosis desalination: A state-of-the-art review. Desalination 2019, 459, 59-104. [CrossRef]

18. Xu, P.; Cath, T.Y.; Robertson, A.P.; Reinhard, M.; Leckie, J.O.; Drewes, J.E. Critical Review of Desalination Concentrate Management, Treatment and Beneficial Use. Environ. Eng. Sci. 2013, 30, 502-514. [CrossRef]

19. Llanos, J.; Cotillas, S.; Cañizares, P.; Rodrigo, M.A. Novel electrodialysis-electrochlorination integrated process for the reclamation of treated wastewaters. Sep. Purif. Technol. 2014, 132, 362-369. [CrossRef]

20. Xu, X.; Lin, L.; Ma, G.; Wang, H.; Jiang, W.; He, Q.; Nirmalakhandan, N.; Xu, P. Study of Polyethyleneimine Coating on Membrane Permselectivity and Desalination Performance during Pilot-scale Electrodialysis of Reverse Osmosis Concentrate. Sep. Purif. Technol. 2018, 207, 396-405.

21. Kwon, K.; Han, J.; Park, B.H.; Shin, Y.; Kim, D. Brine recovery using reverse electrodialysis in membrane-based desalination processes. Desalination 2015, 362, 1-10. [CrossRef]

22. American Water Works Association. Electrodialysis and Electrodialysis Reversal (M38); American Water Works Association: Denver, CO, USA, 1995; Volume 38.

23. Hansima, M.; Makehelwala, M.; Jinadasa, K.; Wei, Y.; Nanayakkara, K.; Herath, A.; Weerasooriya, R. Fouling of ion exchange membranes used in the electrodialysis reversal advanced water treatment: A review. Chemosphere 2020, 127951.

24. McGovern, R.K.; Weiner, A.M.; Sun, L.; Chambers, C.G.; Zubair, S.M. On the cost of electrodialysis for the desalination of high salinity feeds. Appl. Energy. 2014, 136, 649-661. [CrossRef]

25. McGovern, R.K.; Zubair, S.M.; Lienhard, V.J.H. The cost effectiveness of electrodialysis for diverse salinity applications. Desalination 2014, 348, 57-65. [CrossRef] 
26. Xu, P.; Capito, M.; Cath, T.Y. Selective removal of arsenic and monovalent ions from brackish water reverse osmosis concentrate. J. Hazard. Mater. 2013, 260, 885-891. [CrossRef] [PubMed]

27. Geraldes, V.; Afonso, M.D. Limiting current density in the electrodialysis of multi-ionic solutions. J. Membr. Sci. 2010, 360, 499-508. [CrossRef]

28. Sadrzadeh, M.; Razmi, A.; Mohammadi, T. Separation of different ions from wastewater at various operating conditions using electrodialysis. Sep. Purif. Technol. 2007, 54, 147-156. [CrossRef]

29. Zhang, Y.; Desmidt, E.; Van Looveren, A.; Pinoy, L.; Meesschaert, B.; Van der Bruggen, B. Phosphate separation and recovery from wastewater by novel electrodialysis. Environ. Sci. Technol. 2013, 47, 5888-5895. [CrossRef]

30. Abou-Shady, A. Recycling of polluted wastewater for agriculture purpose using electrodialysis: Perspective for large scale application. Chem. Eng. J. 2017, 323, 1-18. [CrossRef]

31. Arola, K.; Ward, A.; Mänttäri, M.; Kallioinen, M.; Batstone, D. Transport of pharmaceuticals during electrodialysis treatment of wastewater. Water Res. 2019, 161, 496-504. [CrossRef]

32. Mohammadi, R.; Ramasamy, D.L.; Sillanpää, M. Enhancement of nitrate removal and recovery from municipal wastewater through single-and multi-batch electrodialysis: Process optimisation and energy consumption. Desalination 2020, $498,114726$. [CrossRef]

33. Al-Amshawee, S.; Yunus, M.Y.B.M.; Azoddein, A.A.M.; Hassell, D.G.; Dakhil, I.H.; Hasan, H.A. Electrodialysis desalination for water and wastewater: A review. Chem. Eng. J. 2020, 380, 122231. [CrossRef]

34. Gurreri, L.; Tamburini, A.; Cipollina, A.; Micale, G. Electrodialysis applications in wastewater treatment for environmental protection and resources recovery: A systematic review on progress and perspectives. Membr 2020, 10, 146. [CrossRef]

35. Walker, W.S.; Kim, Y.; Lawler, D.F. Treatment of model inland brackish groundwater reverse osmosis concentrate with electrodialysis_-Part II: Sensitivity to voltage application and membranes. Desalination 2014, 345, 128-135. [CrossRef]

36. Lee, H.J.; Sarfert, F.; Strathmann, H.; Moon, S.H. Designing of an electrodialysis desalination plant. Desalination 2002, 142, 267-286. [CrossRef]

37. Walker, W.S.; Kim, Y.; Lawler, D.F. Treatment of model inland brackish groundwater reverse osmosis concentrate with electrodialysis-Part I: Sensitivity to superficial velocity. Desalination 2014, 344, 152-162. [CrossRef]

38. Warsinger, D.M.; Swaminathan, J.; Guillen-Burrieza, E.; Arafat, H.A. Scaling and fouling in membrane distillation for desalination applications: A review. Desalination 2015, 356, 294-313. [CrossRef]

39. Walker, W.S.; Kim, Y.; Lawler, D.F. Treatment of model inland brackish groundwater reverse osmosis concentrate with electrodialysis-Part III: Sensitivity to composition and hydraulic recovery. Desalination 2014, 347, 158-164. [CrossRef]

40. Myint, M.T. Saving energy consumption and CO2 emission from sustainable efficient operating zones in inland electrodialysis reversal desalination. Water Resour. Ind. 2014, 5, 36-48. [CrossRef]

41. Krol, J.; Wessling, M.; Strathmann, H. Concentration polarization with monopolar ion exchange membranes: Current-voltage curves and water dissociation. J. Membr. Sci. 1999, 162, 145-154. [CrossRef]

42. Rubinstein, I.; Warshawsky, A.; Schechtman, L.; Kedem, O. Elimination of acid-base generation ('water-splitting') in electrodialysis. Desalination 1984, 51, 55-60. [CrossRef]

43. Lee, H.-J.; Strathmann, H.; Moon, S.-H. Determination of the limiting current density in electrodialysis desalination as an empirical function of linear velocity. Desalination 2006, 190, 43-50. [CrossRef]

44. Cowan, D.A.; Brown, J.H. Effect of turbulence on limiting current in electrodialysis cells. Ind. Eng. Chem. 1959, 51, 1445-1448. [CrossRef]

45. Tanaka, Y. Current density distribution and limiting current density in ion-exchange membrane electrodialysis. J. Membr. Sci. 2000, 173, 179-190. [CrossRef]

46. Xu, X.; He, Q.; Ma, G.; Wang, H.; Nirmalakhandan, N.; Xu, P. Selective separation of mono-and di-valent cations in electrodialysis during brackish water desalination: Bench and pilot-scale studies. Desalination 2018, 428, 146-160. [CrossRef]

47. Todeschini, S.; Perreault, V.; Goulet, C.; Bouchard, M.; Dubé, P.; Boutin, Y.; Bazinet, L. Assessment of the Performance of Electrodialysis in the Removal of the Most Potent Odor-Active Compounds of Herring Milt Hydrolysate: Focus on Ion-Exchange Membrane Fouling and Water Dissociation as Limiting Process Conditions. Membranes 2020, 10, 127. [CrossRef]

48. Tanaka, Y. Concentration polarization in ion-exchange membrane electrodialysis-The events arising in a flowing solution in a desalting cell. J. Membr. Sci. 2003, 216, 149-164. [CrossRef]

49. Sadrzadeh, M.; Razmi, A.; Mohammadi, T. Separation of monovalent, divalent and trivalent ions from wastewater at various operating conditions using electrodialysis. Desalination 2007, 205, 53-61. [CrossRef]

50. Lee, H.-J.; Song, J.-H.; Moon, S.-H. Comparison of electrodialysis reversal (EDR) and electrodeionization reversal (EDIR) for water softening. Desalination 2013, 314, 43-49. [CrossRef]

51. Han, L.; Galier, S.; Roux-de Balmann, H. Ion hydration number and electro-osmosis during electrodialysis of mixed salt solution. Desalination 2015, 373, 38-46. [CrossRef]

52. Ma, G.; Xu, X.; Tesfai, M.; Wang, H.; Xu, P. Developing anti-biofouling and energy-efficient cation-exchange membranes using conductive polymers and nanomaterials. J. Membr. Sci. 2020,603, 118034. [CrossRef]

53. Cooke, B. Concentration polarization in electrodialysis-I. The electrometric measurement of interfacial concentration. Electrochim. Acta. 1961, 3, 307-317. [CrossRef] 
54. Valero, F.; Arbós, R. Desalination of brackish river water using Electrodialysis Reversal (EDR): Control of the THMs formation in the Barcelona (NE Spain) area. Desalination 2010, 253, 170-174. [CrossRef]

55. Sata, T.; Teshima, K.; Yamaguchi, T. Permselectivity between two anions in anion exchange membranes crosslinked with various diamines in electrodialysis. J. Polym. Sci. Part A Polym. Chem. 1996, 34, 1475-1482. [CrossRef]

56. Zhang, Y.; Ghyselbrecht, K.; Meesschaert, B.; Pinoy, L.; Van der Bruggen, B. Electrodialysis on RO concentrate to improve water recovery in wastewater reclamation. J. Membr. Sci. 2011, 378, 101-110. [CrossRef]

57. Kwon, B.; Lee, S.; Cho, J.; Ahn, H.; Lee, D.; Shin, H.S. Biodegradability, DBP formation, and membrane fouling potential of natural organic matter: Characterization and controllability. Environ. Sci. Technol. 2005, 39, 732-739. [CrossRef] [PubMed]

58. Christensen, P.; Dysert, L.R.; Bates, J.; Burton, D.; Creese, R.C.; Hollmann, J. Cost Estimate Classification System-As Applied in Engineering, Procurement, and Construction for the Process Industries; AACE, Inc: Morgantown, WV, USA, 2011. 